\title{
Volcanological and environmental controls on the Snowdon mineralization, North Wales, UK: A failed volcanogenic massive sulfide system in the Avalon Zone of the British Caledonides
}

\author{
Paul A. J. Lusty ${ }^{\mathrm{a}, *}$, Alicja M. Lacinska ${ }^{\mathrm{a}}$, Ian Millar ${ }^{\mathrm{b}}$,Craig D. Barrie ${ }^{\mathrm{c}, 1}$, Adrian J. Boyce ${ }^{\mathrm{c}}$ \\ ${ }^{a}$ British Geological Survey, Environmental Science Centre, Keyworth, Nottingham, NG12 5GG, United Kingdom \\ ${ }^{\mathrm{b}}$ NERC Isotope Geoscience Laboratory, Keyworth, Nottingham, NG12 5GG, United Kingdom \\ ${ }^{\mathrm{c}}$ Scottish Universities Environmental Research Centre, East Kilbride G75 0QF, Scotland, United Kingdom \\ ${ }^{1}$ Present address: Organic Geochemistry Laboratory, GeoMark Research Ltd., 9748 Whithorn Dr., Houston, Texas 77095, \\ USA \\ * Corresponding author at: British Geological Survey, Environmental Science Centre, Keyworth, Nottingham, NG12 5GG, \\ United Kingdom.E-mail address: plusty@bgs.ac.uk
}

Keywords: Snowdon; submarine caldera; VMS; Avalon Zone; British Caledonides; U-Pb

\section{Abstract}

The Snowdon caldera of North Wales is host to base metal sulfide-bearing veins and stockworks, mineralized breccias, disseminated sulfides, and localized zones of semi-massive to massive sulfide, with subordinate magnetite-rich veins. The late Ordovician host volcanic sequence accumulated in a shallow marine, back-arc environment in the Welsh Basin, which forms part of the Avalon Zone of the British and Irish Caledonides. New field evidence, sulfur isotopes, and U-Pb dating indicate that the Snowdon mineralization is genetically and temporally related to Late Ordovician magmatism and caldera formation. It is interpreted to represent volcanogenic pipe-style sulfide mineralization, resulting from focused hydrothermal fluids moving along caldera-related faults and simultaneous dispersal of fluids through the volcaniclastic pile. Sulfur isotope data suggest that, whilst a limited contribution of magmatic $\mathrm{S}$ cannot be ruled out, thermochemical reduction of contemporaneous Ordovician seawater sulfate was the dominant mechanism for sulfide production in the Snowdon system, resulting in a mean value of about $12 \%$ in both the host volcanic strata and the mineralized veins. Despite the tectonic setting being prospective for VMS deposits, strata-bound sulfide accumulations are absent in the caldera. This is attributed to the shallow water depths, which promoted boiling and the formation of sub-seafloor vein-type mineralization. Furthermore, the tectonic instability of the caldera and the high energy, shallow marine environment would have limited preservation of any seafloor deposits. The new $\mathrm{U}-\mathrm{Pb}$ dates for the base (454.26 $\pm 0.35 \mathrm{Ma})$ and top ( $454.42 \pm 0.45 \mathrm{Ma}$ ) of the host volcanic rocks, indicate that the Snowdon magmatic activity was short lived, which is likely to have limited the duration and areal extent of the ore-forming system. 
The absence of massive sulfide mineralization is consistent with the general paucity of economic VMS deposits in the Avalon Zone. Despite the highly prospective geological setting this study further illustrates the importance of volcanic facies mapping and associated paleo-environmental interpretations in VMS exploration.

\section{Introduction}

Calderas formed by the eruption of magma from a sub-surface chamber and subsequent collapse, represent important ore-forming environments. They are commonly loci for dynamic hydrothermal systems driven by heat and magmatic volatiles derived from sub-surface magma, which exploit the extensive structural and stratigraphic permeability (Stix et al. 2003). Globally, the spatial association between mineral deposits and calderas is well established (e.g. Ohmoto, 1978; 1996; Lipman, 1992; Elston, 1994; Rytuba, 1994; Stix et al. 2003). However, the temporal and genetic links between ore formation and caldera development, particularly the specific stages in caldera evolution, are frequently less clear (Guillous-Frottier et al. 2000). Whilst mineralization typically develops towards the end of the caldera cycle, temporal relationships can be highly variable, with volcanism and mineralization being separated by as much as several million years (Lipman, 1992; Rytuba, 1994; Guillous-Frottier et al. 2000). There are also a number of examples where structures associated with calderas and regional extension are important controls for considerably later, genetically-unrelated magmatic and hydrothermal events (e.g. Lipman, 1992; Rytuba et al. 1990; Elston, 1994).

The Snowdon caldera of North Wales, a resurgent rhyolitic caldera, formed in the Caradoc (late Ordovician) within a shallow marine environment (Howells et al. 1986; 1991; Campbell et al. 1987; 1988). The caldera succession, comprising bimodal subaerial to subaqueous volcanic rocks and associated intrusions, overlies Ordovician sedimentary rocks (Thorpe et al. 1993). It is host to numerous base metal sulfide veins and localized occurrences of magnetite-rich mineralization, distributed over an area of about $70 \mathrm{~km}^{2}$ (Fig. 1).

In the model of Reedman et al. (1985) the Snowdon mineralization was the result of a subcaldera intrusion driving convective circulation of seawater and magmatic fluids through calderarelated fractures, leaching metals from the host rocks, and depositing metals at a late stage in the evolution of the caldera. However, the link between the caldera-hosted mineralization and Caradoc magmatism is based solely on their close spatial association and any genetic relationship remains conjectural. Mineralization is constrained to a 40-50 Ma window, as it post-dates the deposition of a major basaltic volcanic formation and pre-dates regional metamorphism and cleavage development (Reedman et al., 1985). Widespread Devonian metamorphic resetting of $\mathrm{Rb} / \mathrm{Sr}$ isotope systems in North Wales means that the age of the spatially associated intrusive and extrusive volcanic rocks (Evans, 1990) is poorly constrained. 
Here we present new field observations, sulfur isotope data, and U-Pb zircon dates, which suggest that the Snowdon mineralization is genetically and temporally related to Caradoc-age magmatism and caldera formation. We compare the Snowdon mineralization and its geological setting with those of volcanogenic massive sulfide (VMS) deposits, and consider why the Snowdon caldera failed to produce strata-bound sulfide accumulations.

\section{Geological setting}

\subsection{Regional geological setting}

The Lower Palaeozoic rocks of Wales consist of a thick sequence of principally marine sedimentary and intercalated volcanic rocks that accumulated in the Welsh Basin (Howells et al. 1991). The basin was located on late Precambrian continental crust composed of accreted island arcs (Thorpe et al. 1984), and formed part of Eastern Avalonia (Kokelaar et al. 1984). During the Ordovician, the Welsh Basin was located close to an ensialic convergent plate margin, probably active from late Tremadoc to Caradoc times (Kokelaar et al. 1988; Howells et al. 1991). It is thought that convergence of Eastern Avalonia with Laurentia caused south-east subduction of Iapetus oceanic crust beneath Wales, resulting in arc volcanism in the Tremadoc (c. 485-478 Ma) (Kokelaar et al. 1984; Kokelaar, 1992). Subsequent back-arc extension in Wales during the Arenig (c. 478-467 Ma) to Caradoc (c. 458-448 Ma) resulted in tholeiitic volcanism, with the main arc located further north in the 'Lake District — Leinster Zone' of the Caledonides (Kokelaar et al. 1984). The tectonic regime in Wales during the Ordovician time is thought to have been sinistrally transtensional, principally resulting from oblique subduction (Kokelaar, 1992).

The location of Ordovician eruptive centres in Wales was influenced by major deep-seated fractures within the ensialic basement (Campbell et al. 1988, Kokelaar, 1988). Arenig to Caradoc age volcanics developed in a complex extensional marine basin (>150 km wide), close to the site of the earlier Tremadoc arc (Kokelaar, 1992). Major volcanism and subsidence within the basin was focussed along relatively narrow, repeatedly subsiding graben systems, controlled by faults splaying off deep-seated basement fractures (Howells et al. 1991; Kokelaar, 1992). In North Wales, an approximately $40 \mathrm{~km}$-wide structural belt, termed the 'Snowdon Graben' (Kokelaar, 1988) or 'failed rift' (Campbell et al. 1988) developed from east-west extension along a north-north-east basement fracture (Kokelaar, 1992) (Fig. 1).

\subsection{The Snowdon Volcanic Group}

The geology of Snowdonia is described in detail by Howells et al. (1991), Howells and Smith (1997) and references therein. The Caradoc rocks of North Wales can be divided into two eruptive cycles: the lower (1st Eruptive Cycle) Llewelyn Volcanic Group and the upper (2nd Eruptive Cycle) 
Snowdon Volcanic Group (SVG) (Howells et al. 1991) (Fig. 1). The SVG, which is the principal host to the mineralization discussed in this work, represents the peak of volcanism in the Snowdon Graben (Kokelaar, 1992). Development of the Snowdon Volcanic Centre was strongly influenced by four north-east to north-north-east trending fracture zones (Howells et al. 1991) (Fig. 1). The SVG in the vicinity of Mount Snowdon, in upward succession, comprises: the Lower Rhyolitic Tuff Formation (LRTF) representing a major acidic caldera-forming phase; the overlying Bedded Pyroclastic Formation (BPF) derived from a period of post-caldera basaltic volcanism; and the Upper Rhyolitic Tuff Formation (URTF) indicating a return to acidic volcanism (Howells et al. 1991) (Figs. 1 and 2). The SVG principally overlies Ordovician marine siliclastic rocks of the Cwm Eigiau Formation (part of the Ogwen Group), comprising siltstones and sandstones with subordinate silty mudstones (Howells and Smith, 1997). Older Ordovician and Upper Cambrian sedimentary rocks surround the caldera (Fig. 1).

The LRTF is up to $600 \mathrm{~m}$ thick, and interpreted to represent a major period of acidic ash-flow tuff eruption and caldera collapse in central Snowdonia (Howells et al. 1986). It comprises sedimentary and pyroclastic breccias, acidic massive welded and non-welded ash-flow tuffs, reworked and remobilized tuffs, intrusive and extrusive rhyolites, rhyolite breccias and marine sediments (Howells et al. 1986; 1991). The LRTF caldera, which has a diameter of about $12 \mathrm{~km}$, is interpreted by these authors to represent a trapdoor structure. The LRTF was largely deposited and extensively reworked in a shallow marine environment, interpreted to range from below storm-wave base to above fair-weather wave base (Howells et al. 1991; Howells and Smith, 1997).

The BPF is up to $450 \mathrm{~m}$ thick, and dominated by tuffaceous sedimentary rocks of basaltic origin, intrusive and extrusive basalts, hyaloclastites and localized areas of basic tuffites. The BPF was deposited in a tectonically active, shallow marine environment where volcanic islands and subaerial vent structures periodically developed (Kokelaar, 1992). Howells and Smith (1997) suggest that small basaltic volcanoes were the principal source of the volcaniclastic debris with periodic catastrophic rates of supply. Major erosional breaks are absent from the thickest section of the intracaldera tuff sequence, and the LRTF is conformably overlain by the basaltic rocks of the BPF (Howells et al., 1986).

In central Snowdonia the BPF is overlain by the URTF, representing the final phase of volcanic activity at the Snowdon Centre. This comprises acidic ash-flow tuffs, bedded tuffs and tuffites, and is up to $100 \mathrm{~m}$ in thickness.

In summary, it is suggested that the Snowdon caldera succession was largely deposited in a highenergy and dynamic shallow marine environment affected by tectonic and magmatic subsidence and uplift, magmatic explosivity, gravitational collapse, slumping, debris flows, turbidity currents and wave action (Howells et al., 1991).

\subsubsection{Rhyolites and subvolcanic intrusions}


Intrusive and extrusive rhyolites are a conspicuous feature of the LRTF caldera (Figs. 1 and 2). They occur as dykes, sills, small stocks and larger domes the lattermost up to $1 \mathrm{~km}$ in diameter. The rhyolites are locally feldspar-phyric, columnar-jointed, flow-banded and autobrecciated. Near surface emplacement caused doming and slumping of overlying unlithified marine sediments. Where the rhyolite masses broke the surface autobrecciation carapaces developed (Campbell et al. 1987). Three main phases of rhyolite emplacement were defined by Campbell et al. (1987):

(i) Immediately before the main LRTF caldera-forming eruptions;

(ii) During caldera resurgence and reworking of the LRTF tuffs, and during the early stages of deposition of the BPF; and

(iii) During emplacement of the URTF.

Five rhyolite groups (A1, A2, B1, B2 and B3) can be distinguished on the basis of geochemistry, each of which has distinct stratigraphic and spatial relationships (Campbell et al. 1987) (Fig. 2).

Various subvolcanic intrusions are associated with the Snowdon Centre, including rhyolites, feldspar porphyries, microgranites, dolerites and basalts. A single andesitic intrusion is present. Three major acidic plutons of probable Ordovician age, but not clearly related to the SVG or earlier volcanic activity, occur within the district (Howells et al. 1991) (Fig. 1).

\subsubsection{Petrochemistry}

Detailed reviews of the petrography, geochemistry and genesis of the SVG and associated rocks are provided by Howells et al. (1991) and Thorpe et al. (1993). The SVG is essentially a bimodal, subalkaline, basalt-rhyolite suite, containing few intermediate rocks. The dominant magmatic affinity of the SVG is calc-alkalic, transitional to tholeiitic (Thorpe et al. 1993). Mafic lavas and intrusions of the BPF mainly have within-plate signatures, which may be associated with arc-rifting, but arc basalts and ocean-island basalts also occur (Howells et al. 1991; Thorpe et al. 1993). These authors proposed that sill-like reservoirs of mantle-derived basaltic magma of variable composition accumulated at the base of the lithosphere, and that these magma bodies underwent fractional crystallization accompanied by minor crustal assimilation, resulting in a range of rhyolitic magmas. These rhyolitic magmas formed small, short-lived, high-level magma chambers (Leat et al. 1986; Thorpe et al. 1993). Three principal magmatic compositions are represented by the SVG: subalkaline basalt, rhyolite and a transitional rhyolite-comendite/pantellerite (Howells et al. 1991). The LRTF is geochemically similar to the group A1 and A2 rhyolites, whilst the URTF is comparable to the group B3 rhyolites (Fig. 2) (Thorpe et al. 1993).

\subsubsection{Structure}

Major north-east-striking faults controlled the shape of the Snowdon Graben and accommodated and partitioned compressive stress during Caledonian deformation (Howells and Smith, 1997). Significant uplift and faulting accompanied the migration of magma to surface. Emplacement of the 
LRTF and associated caldera subsidence would have reactivated existing structures and generated new fracture systems. Regional subsidence and fault propagation continued during emplacement and reworking of the BPF (Howells et al. 1991). Caledonian regional deformation of early to midDevonian (Acadian) age deformed the rocks of North Wales (Howells et al. 1991), resulting in isoclinal, upright to overturned folds and an associated penetrative cleavage (Campbell et al. 1985). Metamorphic grade was up to greenschist facies (Merriman and Roberts, 1985).

\subsubsection{Mineralization}

The Snowdon mineralization was exploited between the mid-19th to early 20th century, with the principal focus on copper and lead production. More recent mineral exploration was conducted by Noranda Kerr (UK) Ltd. around Hafod-y-Llan in the 1970s (Fig. 1).

Mineralization is principally concentrated in a north-east trending corridor, representing the centre of the proposed graben structure (Beddgelert Fault Zone) (Fig. 1). Additional occurrences are located on the northern and western flanks of the caldera (Reedman et al. 1985).

Most of the Snowdon sulfide mineralization occurs close to the base of the BPF and in the upper part of the underlying LRTF (Fig. 2). At Britannia, mineralization straddles the contact between the LRTF and the BPF (occurrence 1 in Fig. 2). Magnetite-rich mineralization occurs in the basal part of the LRTF at Cwm Tregalan and Shadow Gully (occurrences 2 and 3 in Fig. 2) (Colman and Appleby, 1991). At Nantmor, veins are hosted in sub-LRTF sedimentary rocks of the Cwm Eigiau Formation (Reedman et al. 1985) (occurrence 9 in Fig. 2). The URTF appears to be unmineralized.

The mineralization comprises sub-vertical veins, disseminations and stockworks (Ball and Colman, 1998). The principal gangue mineral is quartz, with carbonates reported only from Britannia. Pyrite is the dominant sulfide with subordinate amounts of chalcopyrite and sphalerite, localized occurrences of pyrrhotite, galena and magnetite, and rare native copper, hematite, marcasite, azurite and covellite (Reedman et al. 1985). These authors define five distinct mineral assemblages of varying abundance and distribution, four of which are sulfide dominated, while the fifth is a quartzmagnetite-hematite-pyrite association. The veins have two broad directional trends: (1) north-east, subparallel to the strike of bedding and cleavage, and most abundant in the central graben zone (e.g. Hafod-y-Porth, Hafod-y-Llan); and (2) north-west, discordant to the regional strike of bedding and cleavage (e.g. Britannia, Lliwedd and Moel Hebog) (Reedman et al. 1985) (Fig. 1).

According to Ball and Colman (1998), who studied wall-rock alteration associated with the Snowdon mineralization, samples of the LRTF from in the caldera have depletion in zinc, copper and lead relative to those from outside the caldera, and strong addition of potassium and barium. Anomalous fluorine levels occur in alteration zones surrounding the mineralized veins (Ball and Colman, 1998). These authors concluded that the Snowdon caldera hosted an extensive hydrothermal system that resulted in pervasive K-metasomatism of the volcanic rocks and formed sulfide veins within well-developed alteration zones. 


\section{Sampling and analytical methods}

217 Following reconnaissance visits to the main mineral occurrences in the caldera (Fig. 1), the 218 Hafod-y-Porth and Lliwedd mine areas were selected for detailed study because of their location 219 within the structurally important Beddgelert Fault Zone, they represent mineralization at different 220 stratigraphic levels in the SVG (Fig. 2), they contain a contrasting range of volcanic facies, and the 221 extensive mine workings provide relatively large areas of exposure. Mapping was undertaken at scales of 1:2500 and 1:500 at the Hafod-y-Porth and Lliwedd mines (Fig. 3), with an emphasis on volcanic facies variation, and ground magnetic surveys were locally conducted to aid interpretation of the geology. Representative samples were collected from outcrops and mine waste tips for geochemical, mineralogical, sulfur isotope and geochronological studies.

Petrographic studies were based on 60 new polished thin sections, as well as 80 polished thin sections made available by the British Geological Survey (BGS), and which resulted from a previous BGS study (Howells et al. 1991) of Ordovician marginal basin volcanism in North Wales. An additional 14 polished blocks were prepared for optical and scanning electron microscopy (SEM) prior to laser sulfur-isotope analysis. SEM work was performed using a LEO 435 VP microscope operated under conditions of high vacuum $\left(<1.2 \times 10^{-4}\right.$ torr $)$ at $20 \mathrm{kV}$ accelerating voltage, $19 \mathrm{~mm}$ optimal analytical working distance and an X-ray detector take-off angle of $45^{\circ}$. Mineral identification was aided by qualitative observation of X-ray spectra, using an Oxford Instruments INCA energy-dispersive X-ray microanalysis (EDS) system. Gold analysis was performed using FEI Company Quanta 600 environmental SEM equipped with an Oxford Instruments INCA Energy 450 energy-dispersive X-ray microanalysis system with a $50 \mathrm{~mm}^{2}$ Peltier-cooled silicon drift X-ray detector. The following conditions were used: $20 \mathrm{kV}$ accelerating voltage, spot size 5.5, $10 \mathrm{~mm}$ working distance; with an INCA settings data livetime of $6 \mathrm{~s}$ and process time of $5 \mathrm{~s}$.

The geochemistry of the mineralization was studied using 82 sulfide- and magnetite-rich samples

241 Snowdonia. The 59 new samples collected during this study each comprised 3-4 kg of rock chips,

242 either collected from individual float blocks or over a few tens of centimetres of outcrop. Of the 82

243 samples from the Snowdon caldera, 71 contain quartz-sulfide assemblages (from 8 localities), and 11

244 contain quartz-magnetite assemblages (from 2 localities) (Fig. 1, Table 1). The new samples were

245 crushed and milled at the BGS prior to analysis at Acme Analytical Laboratories (Vancouver,

246 Canada). A 4-acid digestion was conducted on a $0.25 \mathrm{~g}$ split before analysis for 41 elements by

247 inductively coupled plasma-mass spectrometry (ICP-MS). This was accompanied by a fire-assay fusion on a $30 \mathrm{~g}$ split prior to analysis for $\mathrm{Au}, \mathrm{Pt}$ and $\mathrm{Pd}$, by ICP-MS. Values below detection limit have been replaced with half of the limit of detection. The maximum level of determination was $10,000 \mathrm{ppm}$ for $\mathrm{Cu}, \mathrm{Pb}, \mathrm{Zn}$ and $\mathrm{Mn}$. Values of 10,000 ppm were used for calculating mean and 
median values, although maximum metal concentrations could be higher. The trace element data used to compare the composition of the SVG with other mineralized felsic volcanic rocks (section 9.3.) is derived from previous work (as indicated in Appendix A and the caption for Fig. 12).

17 country rock samples were collected to produce sulfide concentrates for sulfur isotope analysis. Only seven samples yielded sufficient sulfide for analysis, including one sample of the Myndd Mawr microgranite. Following sample crushing, sulfides were removed by hand picking under a binocular microscope. Conventional S isotope analyses (Robinson and Kuskabe 1975) were complemented with in-situ laser analyses (Wagner et al., 2002), conducted at the Scottish Universities Environmental Research Centre (SUERC). The laser analyses were carried out on 14 mineralized rock samples. The purified $\mathrm{SO}_{2}$ samples were measured on a gas-source isotope-ratio mass spectrometer. All results are reported as $\delta^{34} \mathrm{~S}$ permil values, relative to 'Vienna Canon Diablo Trolite' (i.e. $\delta^{34} \mathrm{~S}$ V-CDT). Typical reproducibility based on repeat analyses of international standards is about $\pm 0.3 \%$.

A geochronological study was conducted in an attempt to determine the volcanic history of the Snowdon caldera. Ten samples were submitted to the NERC Isotope Geosciences Laboratory (NIGL) for separation of zircons and assessment of their potential for U-Pb dating by Isotope Dilution Thermal Ionisation Mass Spectrometry (ID-TIMS). However, most of the samples were either poor in zircon, or contained rounded, presumably inherited populations. The most promising zircon population was obtained from a sample of rhyolite tuff collected close to the base of the LRTF (sample SMM157 in Figs. 1 and 2). A sample of rhyolite tuff from the URTF (sample SMM154 in Figs. 1 and 2) also contained abundant zircons, although a significant proportion were rounded. As these two samples come from close to the top and bottom of the SVG, their ages should in theory bracket the age of the caldera volcanism. Zircons were isolated using conventional mineral separation techniques, then subjected to chemical abrasion (Mattinson, 2005), and analysed using ID-TIMS. For details of the analytical method, see Appendix B. Errors for U-Pb dates are reported in the following format: $\pm \mathrm{X}(\mathrm{Y})[\mathrm{Z}]$, where $\mathrm{X}$ is the internal or analytical uncertainty in the absence of systematic errors (tracer calibration and decay constants), $\mathrm{Y}$ includes the quadratic addition of tracer calibration error (using a conservative estimate of the standard deviation of $0.1 \%$ for the $\mathrm{Pb} / \mathrm{U}$ ratio in the tracer), and $\mathrm{Z}$ includes the quadratic addition of both the tracer calibration error and additional ${ }^{238} \mathrm{U}$ decay constant errors of Jaffey et al. (1971).

\section{Style of mineralization and relationship to volcanic facies}

\subsection{The Hafod-y-Porth mine}

The Hafod-y-Porth mineralization is located within the Beddgelert Fault Zone, towards the centre of the caldera (Fig. 1). Existing geological mapping (British Geological Survey, 2013) suggests 
that the mineralization is hosted predominantly by the BPF (Fig. 3), in association with a series of linear B1 rhyolite intrusions that have an approximate north-east trend.

\subsubsection{Volcanic facies and structure}

Five distinct volcanic facies were mapped in the Hafod-y-Porth mine area (Fig. 4A):

(i) Basaltic tuff is typically massive and displays well-developed cleavage. It is composed of $>75 \%$ fine ash-sized particles and can contain up to $20 \%, 5-10 \mathrm{~cm}$ angular pyroclastic fragments. Pyroclast composition is largely basaltic, although locally it approaches $50 \%$ rhyolitic.

(ii) Rhyolite lapilli-tuff has a coarse-grained ash matrix and contains pyroclastic fragments, up to $6 \mathrm{~cm}$ and rarely $10 \mathrm{~cm}$ that form up to $60 \%$ of the rock (Fig. 4B). The pyroclasts are mostly angular to sub-rounded and rhyolitic in composition, with variants containing $30-50 \%$ basaltic pyroclasts. The degree of pyroclastic fragment alignment to cleavage varies from weak to strong. A laminar fabric in the tuff suggests that the flow direction was approximately north-south.

(iii) Welded rhyolite-tuff is a variation of facies ii. The welding foliation is accentuated by silicification, forming pronounced sub-parallel silica ribs (Fig. 4E). In the south of the mapped area (locality HP1 in Fig. 4A), this facies has been brecciated into 30-50 cm sized blocks (Fig. 4D).

(iv) Pyroclastic breccia typically comprises $60 \%$ bomb size fragments, which locally form up to $80 \%$ of the rock. Fragments typically range from $5-20 \mathrm{~cm}$ in size, locally reaching $100 \mathrm{~cm}$, and are mainly angular to sub-angular. Pyroclast composition is typically $>90 \%$ rhyolitic, and bombs of flowbanded rhyolite are common. Minor, accidental basaltic pyroclasts reach $100 \mathrm{~cm}$ in size. Where large pyroclasts are abundant, cleavage and flow fabric are deflected and disrupted.

(v) Massive rhyolite is very restricted in extent (Fig. 4A). It is well-jointed and uncleaved, with local flow-banding. Numerous thin rhyolite dykes (up to $30 \mathrm{~cm}$ in width) are present but they cannot be traced for more than $2 \mathrm{~m}$. They do not have a preferred orientation (Fig. 4A). Pods and blocks of autobrecciated rhyolite characterised by angular fragments of rhyolite, which commonly have a jigsaw fit, occur locally within the tuff and breccia facies. The fragments typically range from $5-20 \mathrm{~cm}$ in size, but locally reach $100 \mathrm{~cm}$. Spherulitic textures are common.

The strike of the cleavage across the Hafod-y-Porth area varies from $030-090^{\circ}$, but is typically between $040-060^{\circ}$. The dip is generally near vertical and rarely less than $50^{\circ}$, and is almost exclusively to the south-east (Fig. 4A).

\subsubsection{Mineralization}

Quartz veining is abundant in the Hafod-y-Porth area and is typically sub-parallel to the cleavage, although locally veins diverge strongly from the cleavage (Fig. 4A). Three distinct types of quartz veins are present, most of which do not contain sulfides. The most abundant are narrow (typically $<3 \mathrm{~cm}$ wide) quartz veinlets of highly variable orientation. These locally form dense arrays, 
with discreet veins rarely traceable for more than $100 \mathrm{~cm}$. These veinlets, which lack sulfide, have well-developed comb textures and display evidence for east-west shortening as indicated by the development of crenulations. These are cross-cut by a second generation of veins, which extend along strike for up to $4 \mathrm{~m}$, but pinch and swell, ranging in width from 1-30 cm. These veins are generally steeply dipping, have a north-east trend and are variably sulfide-bearing. A third set of veins cuts and locally offsets the previous two generations, forming dense arrays and thick sheets. This generation of veins is composed of massive, homogenous, milky white quartz. In terms of timing relationships, it is notable that angular fragments of rhyolite within the lapilli-tuff rarely contain discrete quartz veins (Fig. 4B). These veins are restricted to the pyroclasts, indicating that they formed prior to incorporation in the tuff. The veins within the pyroclasts range in width from 2 to $20 \mathrm{~mm}$ and have open-space textures.

Mineralized breccia zones, which typically lack well-defined margins and are laterally impersistent are common (Figs. 4C and 5A). These comprise angular rock fragments with local jigsaw fit, cemented by a microcrystalline quartz-sulfide matrix (Fig. 5B-E).

Disseminated sulfides are widespread in the wall rocks adjacent to the mineralization (Fig. 4C) but overall are much less abundant than the vein-hosted sulfides. Sulfide veinlets and disseminations containing little or no visible quartz mainly occur in the basaltic tuff (Fig. 5F). Fracture-controlled mineralization and disseminations of quartz and sulfide frequently occur in the same samples (Fig. 5E,G). Small rhyolite dykes (Fig. 4A) that intrude the volcaniclastic rocks are also mineralized.

The sulfide mineralization at Hafod-y-Porth is preferentially hosted by coarse-grained, poorlysorted, felsic lithologies, particularly brecciated variants of the welded rhyolite tuff and the pyroclastic breccia (Fig. 4C-E). Remnant zones of historical mineral extraction up to $5 \mathrm{~m}$ wide indicate the existence of much more substantial veins or mineralized breccias (Fig. 4C).

Quartz in the sulfide-bearing veins and breccias varies from microcrystalline (Fig. 5B, C) to comb-textured, with prismatic crystals up to $5 \mathrm{~mm}$ in length (Fig. $5 \mathrm{H}$ ). At least four quartz generations are evident in some samples, forming alternating layers of microcrystalline quartz, sulfides and comb quartz (Fig. 5H). The quartz contains irregular grains and patches of chalcopyrite, galena and sphalerite (up to $1 \mathrm{~cm}$ size) and locally euhedral pyrite crystals (Fig. 5B-D). Rare, acicular crystals of graphite, up to $3 \mathrm{~mm}$ in length occur in the quartz (Fig. 5C). There is no evidence for brecciation and re-cementation of previously deposited sulfide mineralization. Dark alteration haloes are locally developed around both fractured hosted and disseminated sulfides (Fig. 5G). Chloritization has altered lithic fragments in the veins and adjacent wall rock to a green-grey colour (Fig. 5B, H).

\subsection{The Lliwedd mine}

The Lliwedd mineralization is located at the northern end of the Beddgelert Fault Zone (Fig. 1). Published geological maps indicate that mineralization is located in the BPF, proximal to B3 rhyolite 
intrusions (Fig. 3). The principal mineralized zone at Lliwedd trends west-north-west before changing to an approximate east-west orientation half way along its length (Fig. 3).

\subsubsection{Volcanic facies and structure}

In the area where the Lliwedd mineralized zone changes orientation (Fig. 3), three volcanic facies can be distinguished in the BPF: pillow lavas, massive basalt and basaltic lapilli-tuff (Fig. 6A). Pillow structures typically ranging from $20-60 \mathrm{~cm}$ in width, form a distinctive unit (Fig. 6A-C). The massive basalt is gradational to the pillows, while the basaltic lapilli-tuff is interbedded with the pillows. The lapilli-tuff consists of a fine-grained, blue to green ash matrix containing about $30 \%$ variably orientated, subrounded to angular, pyroclastic fragments up to $3 \mathrm{~mm}$ in size. Within the lapilli-tuff are conspicuous rounded, but deformed, quartz-rich inclusions up to $5 \mathrm{~mm}$ in width. The quartz-rich inclusions are chloritized and locally contain grains of pyrite, which also occur disseminated throughout the tuff. Both the massive basalt and the basaltic tuff have a prominent cleavage that strikes between $040-060^{\circ}$ (Fig. 6A) and dips steeply.

\subsubsection{Mineralization}

Three types of veins are evident in the Lliwedd area. Networks of narrow (typically $<1 \mathrm{~cm}$ wide), steeply dipping, contorted quartz stringers are well developed in the pillow basalts, frequently around the pillow boundaries (Fig. 6C). These veins, which lack any preferred orientation, locally contain chalcopyrite and pyrite, with subordinate bornite and native copper. A second vein set crosscuts the pillow lavas and basaltic tuffs, locally offsetting the stringer veins (Fig. 6C). These veins are typically up to $4 \mathrm{~cm}$ wide and can be traced along strike for up to $10 \mathrm{~m}$. They are steeply dipping and generally have an east-west orientation (Fig. 6A). The veins are not uniformly sulfide-bearing along their length, but range from near barren to zones with abundant pyrite and chalcopyrite (Fig. $6 \mathrm{D})$. The third vein style consists of dense arrays of veins that pinch and swell to form pods of massive, milky white quartz of probable metamorphic origin. This vein type is also present at Hafody-Porth and ubiquitous to the Snowdon area.

The basaltic lapilli-tuff adjacent to the mineralized pillow lavas (Figs. 6A, B) contains rare 2-10 $\mathrm{cm}$, subangular to subrounded fragments of sulfide-bearing quartz (Fig. 6E). Although the tuff also hosts discreet sulfide-bearing quartz veins, the quartz fragments are epiclastic in origin, having been incorporated into the tuff during deposition or remobilization. Evidence for this includes their oval to sub-rounded form (Fig. 6E-G), sporadic distribution, lack of any association with fractures, and the clear separation of individual quartz fragments by a tuffaceous matrix (Fig. 6F).

Examination of in-situ mineralization and samples from the mine waste tips suggests that the ore zone at Lliwedd consisted of a steeply dipping zone of ramifying quartz-sulfide veinlets, quartzsulfide cemented breccias, disseminated sulfides and localized areas of semi-massive/massive sulfide. As at Hafod-y-Porth, mineralized breccias are common. These breccias comprise angular lithic 
fragments cemented by microcrystalline and prismatic quartz with granular to intergrown sulfides. Some of these breccias display a jig-saw fit texture and well-defined contacts with the wall rock (Fig. $7 \mathrm{~A})$.

Semi-massive/massive sulfide-rich ore is composed of $>80 \%$ sulfides, with little gangue or lithic material, and typically contains intergrown and granular chalcopyrite, pyrite and pyrrhotite with subordinate galena. Irregular-shaped masses of sphalerite up to $3 \mathrm{~cm}$ in size are locally common (Fig. 7B). Heavily silicified variants contain granular aggregates of pyrite-chalcopyrite-pyrrhotite (Fig. 7C). Euhedral to subhedral pyrite grains up to $5 \mathrm{~mm}$ in width, and which are locally zoned, occur in the finer-grained quartz-sulfide matrix (Fig. 7C).

Discrete sulfide-bearing quartz veins occur (Fig. 7D), rarely containing native copper (Fig. 7E), and some of these veins exploit the contacts between lithic fragments (Fig. 7G). Banded veins comprising alternating layers of prismatic quartz crystals of varying size, microcrystalline quartz and sulfides are evidence of multiple episodes of vein growth under open-space conditions (Fig. 7F). Veins show evidence for both asymmetric (Fig. 7F) and symmetric development. Fine-grained disseminated sulfides are a common feature at the Lliwedd mine (Fig. 7E, G).

Pervasive chlorite alteration is evident from the light to dark green colour of lithic fragments and wall rock selvages (Fig. 7D, F); green-grey coloured silicified zones and chlorite-rich depositional layers (Fig. 7C, E); and alteration halos locally developed around veins (Fig. 7G). In some samples sulfide mineralization appears to be preferentially concentrated around lithic fragments and along wall rock contacts (Fig. 7D, F, H). A single sample contains creamy white to pink potassium feldspar intergrown with microcrystalline quartz, in association with chalcopyrite (Fig. 7H). Pink to white Mn-dominated Fe-Ca-Mg carbonate occurs in the quartz of another sample (Fig. 7D).

\section{Ore mineralogy and alteration}

The mineralization in the caldera can be subdivided into two broad categories: (i) quartz-basemetal sulfide rich; and (ii) quartz-magnetite rich. The former is much more abundant. Both types of mineralization occur as veins, breccias and disseminations in the immediate wall rocks, which are generally pervasively chloritized and/or sericitized, with localized intense silicification. The dominant gangue mineral is quartz, while pyrite is the principal sulfide, followed by chalcopyrite and then sphalerite. Pyrrhotite and galena are also locally common. Minor primary phases include marcasite, native copper, magnetite, arsenopyrite, hematite, cassiterite, scheelite, and bismuth and cobalt-bearing minerals. The secondary minerals cuprite, covellite and digenite are also present. Rare $<20 \mu \mathrm{m}$ particles of native gold were identified in $70 \%$ of the samples that underwent automated SEM-feature analysis. Although the proportion of the ore minerals varies significantly between localities Lliwedd, Britannia and Hafod-y-Porth exhibit comparable assemblages of quartz-pyrite-chalcopyrite-sphaleritegalena-pyrrhotite \pm arsenopyrite. Nantmor is distinctive in having a quartz-pyrite-chalcopyrite \pm 
arsenopyrite assemblage while lacking other sulfides. A sample from Hafod-y-Llan contained quartzgalena-sphalerite-chalcopyrite, but lacked pyrite. Unlike the other localities, Hafod-y-Porth contains graphite in association with the sulfide minerals (Fig. 5C). The magnetite-rich assemblage at Shadow Gully consists of magnetite-pyrite-hematite with trace cassiterite and scheelite (the latter two are absent from the other localities).

Fragments of chloritized and/or sericitized wallrock are frequently trapped in the veins, indicating a stage of pre-vein or syn-vein alteration (Fig. 9). The wallrock and veins show variable degrees of deformation, ranging from the development of weak cleavage to localized zones of folding and intense shearing. In the mineralized samples, deformation is manifested by the cataclasis of pyrite and fracturing and shearing of graphite crystals. Fractures within deformed pyrite are sealed by chalcopyrite and pyrrhotite (Fig. 8A, B). Some pyrite crystals have cores rich in inclusions (mainly sphalerite, marcasite and silicate phases) and euhedral to subhedral impurity-free rims. The inclusionrich cores locally show a distinctive helical pattern, indicative of syn-deformational growth of pyrite. The quartz gangue is also deformed, displaying straining, annealed crystal boundaries and localized recrystallization. Local pressure shadows around ore minerals are commonly filled with fibrous chlorite. Relict volcanic textures are evident in some samples, mainly in the more acidic rocks, which are typically less chloritized.

Pyrite forms between 5-50\% of the samples examined under the optical microscope. It is the earliest formed sulfide, and typically occurs as euhedral to subhedral crystals up to $7 \mathrm{~mm}$ in size that form aggregates together with marcasite and other sulfide phases. Some pyrite crystals contain $<50$ $\mu \mathrm{m}$ laths of arsenopyrite, whilst others have arsenic-rich cores. Marcasite occurs as anhedral to subhedral grains and as aggregates of bladed crystals, and locally replaces pyrite. Bird's eye texture in some samples indicates localised derivation of this assemblage from the alteration of pyrrhotite.

Chalcopyrite forms $5-30 \%$ of the samples studied. It locally forms large ( $>1 \mathrm{~mm}$ size) anhedral masses, irregularly intergrown with silicate minerals and other sulfides (Fig. 8A, C). Chalcopyrite also fills fractures in pyrite (Fig. 8B), occurs interstitially to subhedral pyrrhotite grains; and forms inclusions in sphalerite (Fig. 8D). Chalcopyrite is locally altered to cuprite and covellite.

Pyrrhotite, which constitutes up to $20 \%$ of some samples, typically occurs as anhedral to subhedral crystals in massive chalcopyrite, and as fine intergrowths with chalcopyrite \pm pyrite \pm marcasite and locally sphalerite. It also locally forms discrete micro-stringers along quartz crystal boundaries.

With the exception of at Hafod-y-Llan, galena rarely forms $>3 \%$ of the samples. It principally occurs as $<200 \mu \mathrm{m}$ laths, $<30 \mu \mathrm{m}$ anhedral inclusions in chalcopyrite and pyrite, and in fractures cutting pyrite. At Hafod-y-Llan veins of massive galena and quartz are present. The galena hosts anhedral domains of sphalerite and chalcopyrite (Fig. 8D).

Sphalerite forms up to $15 \%$ of some samples. It is typically anhedral and intergrown with chalcopyrite \pm pyrite \pm pyrrhotite \pm galena. Arsenopyrite is a minor phase, occurring as $<50 \mu \mathrm{m}$, 
rhombic crystals scattered through the sulfide-rich groundmass of some samples. Locally, arsenopyrite hosts $<5 \mu \mathrm{m}$ inclusions of galena. Bismuth-rich phases are associated with the base metal sulfides at the majority of the localities studied, and include native bismuth, bismuthinite, $\mathrm{Pb}$ $\mathrm{Bi} \pm \mathrm{Cu}$ sulfide and $\mathrm{Bi}$ selenides. They generally occur as $<50 \mu \mathrm{m}$ anhedral to elongate crystals, forming fine intergrowths with other Bi-rich phases and galena.

Graphite is only found at Hafod-y-Porth, in association with a quartz-chlorite \pm pyrite \pm chalcopyrite assemblage (Figs. 5C and 8E, F). It occurs as either dismembered bundles of bladed crystals up to $1 \mathrm{~mm}$ long, spherical domains $<600 \mu \mathrm{m}$ in diameter that exhibit a radial texture, or as finely-crystalline intergrowths with chlorite.

In the quartz-magnetite veins, magnetite is typically associated with pyrite-hematite \pm scheelite \pm cassiterite (Fig. 8G). Pyrite in this assemblage has distinctive alteration rims, composed of Feoxyhydroxides, K-rich clay minerals and barite. In the Shadow Gully samples, trace barite is a late phase, occupying fractures and voids in both the groundmass and the sulfides (Fig. 8G). Magnetite crystals are generally euhedral to subhedral, ranging in size from $20-400 \mu \mathrm{m}$, and commonly form clusters (Fig. 8G). Hematite inclusions occur in magnetite and pyrite crystals in this assemblage. Cassiterite $(<20 \mu \mathrm{m}$ anhedral crystals $)$ and scheelite $(<100 \mu \mathrm{m}$ anhedral crystals $)$ are scattered throughout the silicate matrix, with cassiterite also occurring as inclusions in the magnetite. At Cwm Tregallan, the magnetite has a distinctive elongate morphology and is intimately associated with chlorite. A generalized paragenetic sequence based on the assemblages and localities described above is presented in Figure 9.

Rare, 1-5 $\mu \mathrm{m}$ gold grains were identified in samples from Hafod-y-Porth, Lliwedd and Nantmor. In a sample from Lliwedd, gold occurs at the grain boundaries between pyrite and chalcopyrite (Fig. $8 \mathrm{H})$. In samples from Hafod-y-Porth, gold was observed in microfractures in galena, at grain boundaries between pyrite and quartz, and in association with graphite.

\section{Bulk geochemistry of the mineralization}

\subsection{Quartz-sulfide assemblage}

Overall the quartz-sulfide veins have $\mathrm{Cu}: \mathrm{Zn}$ and $\mathrm{Cu}: \mathrm{Pb}$ ratios of $>20: 1$. The average $\mathrm{Pb}: \mathrm{Zn}$ ratio is 2:1 (Table 1). The $\mathrm{Cu}$ content, which averages $0.6 \%$ in the 71 quartz-sulfide samples, does not exhibit a strong Spearman rank correlation with any other elements. $\mathrm{Pb}$ and $\mathrm{Zn}$ contents average $0.3 \%$ and show a strong positive correlation, reflecting the common association of galena and sphalerite. $\mathrm{Zn}$ and $\mathrm{Pb}$ have strong correlations with $\mathrm{Cd}(r=0.78$ and $r=0.72$, respectively). $\mathrm{Ag}$ content ranges from below detection limit $(0.1 \mathrm{ppm})$ to $200 \mathrm{ppm}$, and shows moderate correlations with $\mathrm{Sb}(r=0.62)$ and $\mathrm{Cd}(r=0.61)$. Au content ranges from below detection limit (2 ppb) to $0.62 \mathrm{ppm}$, with a mean of 0.14 ppm. Among the trace metals, Co content ranges from 2.4 to $738 \mathrm{ppm}$ and correlates with $\mathrm{Ni}(r=$ 
0.69). As ranges from below detection limit (1 ppm) to $7142 \mathrm{ppm}$, with a mean value of $283 \mathrm{ppm}$. Cd is variably enriched, with two samples containing $>1000 \mathrm{ppm}$. Sb ranges from below detection limit $(0.1 \mathrm{ppm})$ to $752 \mathrm{ppm}$, with a mean of $35 \mathrm{ppm}$ while Bi ranges from below detection limit ( $0.1 \mathrm{ppm})$ to $3885 \mathrm{ppm}$, with a mean of $242 \mathrm{ppm}$. The F content of 66 samples from a legacy BGS dataset ranges from 228-3080 ppm, with a mean of $1064 \mathrm{ppm}$. The highest $\mathrm{F}$ values occur near the northern end of the Beddgelert Fault Zone, around Hafod-y-Porth and Hafod-y-Llan.

\subsection{Quartz-magnetite assemblage}

Relative to the quartz-sulfide veins, the 11 samples of quartz-magnetite veins contain low levels of $\mathrm{Cu}, \mathrm{Pb}, \mathrm{Zn}$ and $\mathrm{Ag}$ (Table 1). Co concentrations are similar in both assemblages. Only two samples of the quartz-magnetite veins contain Au concentrations above detection limit, with a maximum of 96 ppb. As, $\mathrm{Cd}, \mathrm{Sb}$ and Bi concentrations in the quartz-magnetite veins are substantially lower than in the quartz-sulfide veins, whereas $\mathrm{W}$ contents are distinctly higher.

\section{Sulfur Isotopes}

\subsection{Vein sulfides}

Sulfur isotope data were obtained on the following vein sulfides: pyrite, sphalerite, chalcopyrite, galena, arsenopyrite and pyrrhotite (Table 2). The mean $\delta^{34} \mathrm{~S}$ signature for the sulfides in the veins is $+13.0 \pm 3.4 \%$ (Fig. 10A). The volcanic-hosted mineralization (Britannia, Lliwedd, Hafod-y-Porth, Hafod-y-Llan and Shadow Gully) displays $\delta^{34} \mathrm{~S}$ values from $+9.1 \%$ to $+22.3 \%$, with a mean of $+13.6 \%$ $\pm 2.9 \%$. The isotopically lighter values $(+10.9 \%$ to $+15.8 \%$ ) from the mineralization at Hafod-y-Porth overlap with the $\delta^{34} \mathrm{~S}$ signatures from Lliwedd, Britannia and Shadow Gully (Fig. 10A). The $\delta^{34} \mathrm{~S}$ signatures from Hafod-y-Llan are heavier than those from Lliwedd and Britannia. At Shadow Gully, $\delta^{34} \mathrm{~S}$ signatures associated with the quartz-magnetite mineralization range from $+13.6 \%$ to $+16.1 \%$, thus overlapping the $\delta^{34} \mathrm{~S}$ values of the quartz-sulfide mineralization. At Nantmor, two of the three samples of sedimentary rock-hosted quartz-sulfide mineralization have $\delta^{34} \mathrm{~S}$ values ranging from $+11.6 \%$ to $+15.0 \%$, also overlapping the volcanic-hosted mineralization. The third Nantmor sample is distinctive in having $\delta^{34} \mathrm{~S}$ values that are lower $(+3.7 \%$ to $+7.2 \%$ o $)$ than any of the values found in the volcanic-hosted mineralization. The sulfur isotope data indicate that the three types of mineralization cannot be differentiated solely on the basis of their $\delta^{34} \mathrm{~S}$ signatures.

\subsection{Country rock sulfur}


Six samples from the SVG (LRTF, BPF and B3 rhyolites) have $\delta^{34} \mathrm{~S}$ values ranging from +7.0 to $+18.5 \%$, with a mean value of $+11.7 \%$ o $\pm 4.5 \%$ (Fig. $10 \mathrm{~B})$.

\section{Dating of the Snowdon Volcanic Group}

547

Sample SMM157 from the LRTF (Fig. 2) contained a simple population of euhedral igneous zircon crystals with oscillatory zoning and no evidence for cores under cathodoluminescence. Seven single zircon grains were analysed. All seven analyses are concordant when the systematic $\lambda^{238} \mathrm{U}$ and $\lambda^{235} \mathrm{U}$ decay constant errors are considered (Mattinson, 2010) with ${ }^{206} \mathrm{~Pb} /{ }^{238} \mathrm{U}$ dates between c. 454.0 and 455.4 Ma. Excluding one data point that is distinctly older than the main population, the data yield a weighted mean ${ }^{206} \mathrm{~Pb} /{ }^{238} \mathrm{U}$ date of $454.26 \pm 0.35(0.57)[0.76] \mathrm{Ma}$ (mean square weighted deviation: MSWD = 3.0), which we interpret as the best estimate of the age of this sample.

The zircon population of sample SMM154 for the URTF (Fig. 2) showed significantly more variation in morphology and cathodoluminescence characteristics than that of SMM157, with numerous rounded grains and evidence for inherited cores. Five euhedral crystals were selected for analysis. All five analyses are concordant when the systematic $\lambda^{238} U$ and $\lambda^{235} U$ decay constant errors are considered (Mattinson, 2010) with ${ }^{206} \mathrm{~Pb} /{ }^{238} \mathrm{U}$ dates forming a coherent single population yielding a weighted mean ${ }^{206} \mathrm{~Pb} /{ }^{238} \mathrm{U}$ date of $454.42 \pm 0.45(0.64)[0.82] \mathrm{Ma}(\mathrm{MSWD}=1.8)($ Fig. 11).

The two ages from the base and top of the SVG (Fig. 2), which are within error of one another, indicate that the SVG was deposited very rapidly. Inclusion of mineralized fragments within the LRTF and BPF (Figs. 4B and 6E) testify to the existence of unstable conditions during the time of mineralization, and indicate that some mineralization existed prior to deposition of the host tuffs. The main phase of mineralization cross-cuts the LRTF and BPF (Fig. 2), indicating that it post-dates their deposition, although the absolute age of these veins is unknown. Direct dating of the veins using the Re-Os method was attempted, but the very low Re abundance of the sulfides precluded its use.

\section{Discussion}

The key geologic characteristics of the Snowdon mineralization which have a bearing on its classification, and the subsequent discussion are (Table 3):

1. It is located in an ensialic back-arc environment, forming part of the Avalon Zone of the British and Irish Caledonides.

2. It is associated with a structurally complex environment, related to a resurgent asymmetric submarine trapdoor caldera, within a failed rift structure (Howells et al. 1991; Howells and Smith, 1997).

3. Field relationships indicate it spatially and temporally associated with $454 \mathrm{Ma}$ bimodal volcanic rocks and synvolcanic intrusions, with dominantly calc-alkalic, within-plate and OIB 
600

601

602

603

signatures. These volcanics were derived from reservoirs of mantle-derived basaltic magma, and small, short-lived, high-level rhyolitic magma chambers (Leat et al. 1986; Howells et al. 1986; 1991; Thorpe et al. 1993).

4. It is hosted by a variety of a volcaniclastic rocks, lava flows and domes and their related autoclastic deposits and synvolcanic intrusions. The volcanic rocks were rapidly deposited, with no significant hiatus in volcanism, in a high-energy, shallow-water environment (water depths of 10-200 m, with locally subaerial conditions) (Howells et al., 1991).

5. It is principally located in structurally controlled zones, related to synvolcanic faults, with a concentration of mineralization towards the centre of the caldera (Fig. 1). The mineralization occurs at various stratigraphic levels, but is concentrated close to the contact between two major volcanic formations, the felsic LRTF and the mafic BPF (Fig. 2).

6. It occurs as discordant veins, stockworks and quartz-sulfide cemented breccias, which are locally banded and have open-space textures, indicative of repeated episodes of fracturing and sealing, and low confining pressures. Veins and breccias are best developed in coarse, poorlysorted, volcaniclastic rocks and rhyolitic breccias.

7. The principal ore minerals are pyrite-chalcopyrite-sphalerite-galena-pyrrhotite-native copper, and the main gangue mineral is quartz.

8. Mineralization is associated with intense $\mathrm{K}$-metasomatism and pervasive Fe-Mg-chloritequartz-pyrite alteration. There is also evidence for elevated levels of fluorine and leaching of metals from the host volcanic sequence (Ball and Colman, 1998).

9. The mean $\left(+13.0 \% \%_{0} \pm 3.4 \%\right.$ ) and range of $\delta^{34} \mathrm{~S}$ values for sulfide minerals from the mineralization are similar to those for sulfides found in the host volcanic rocks (Fig. 10).

\subsection{VMS mineralization in the Caledonides}

The Snowdon region forms part of the Appalachian-Caledonian orogenic belt extending from Canada, through the USA, into the British Isles and Scandinavia (van Staal, 2007). This belt hosts numerous VMS deposits, including extensive mineralization in New Brunswick, Canada (van Staal and Barr, 2012). Hollis et al. (2014) have emphasised the prospectivity of north-west Wales for VMS mineralization. South of the Iapetus suture, the largest deposits are Avoca in south-east Ireland and Parys Mountain on Anglesey in north-west Wales (Fig. 1). At Avoca, a strata-bound copper sulfide deposit is hosted in Ordovician volcanic rocks. Mineralization consists of massive, banded sulfides, lying stratigraphically immediately above a zone of vein and disseminated sulfides. In the western part of the deposit veins are up to $85 \mathrm{~cm}$ in thickness and are typically composed of chalcopyrite, pyrite and quartz (Williams et al. 1986). Historical production at Avoca was $16 \mathrm{Mt}$ grading $0.6 \% \mathrm{Cu}$ (Williams et al. 1986), and West Avoca has a historical resource of $6.0 \mathrm{Mt}$ grading 5.3\% Zn and 
615 the contact between Ordovician shales and overlying rhyolites (Barrett et al. 2001). The Parys

616 Mountain deposit has a resource of $2.1 \mathrm{Mt}$ at $6.9 \% \mathrm{Cu}+\mathrm{Pb}+\mathrm{Zn}$ in the indicated category, and $4.1 \mathrm{Mt}$ at

$6175.0 \% \mathrm{Cu}+\mathrm{Pb}+\mathrm{Zn}$ in the inferred category (Anglesey Mining, 2015).

618 In terms of deposits sited on Avalonian age basement, the Cae Coch deposit, located $20 \mathrm{~km}$ 619 north-east of the Snowdon Centre (Fig. 1) is associated with the broadly contemporaneous Crafnant 620 Volcanic Centre. It consists of a 2 m-thick stratiform pyrite body ( $0.2 \mathrm{Mt})$, located at the boundary 621 between Caradoc-age bimodal volcanic rocks and overlying black shales (Ball and Bland, 1985;

622 Bottrell and Morton, 1992). At Benallt on the Lleyn Peninsula, strata-bound manganese

623 mineralization occurs in Ordovician mudstones bounded by basic volcanic rocks (Fig. 1). A

624 submarine, exhalative origin has been proposed for this mineralization (Brown and Evans, 1989). In

625 southern Snowdonia, barium enrichment is present in Ordovician sedimentary rocks associated with

626 subaerial to submarine bimodal volcanics (Cooper and Colman, 2000).

627

\subsection{Geodynamic setting of the Snowdon caldera}

629

The geodynamic setting of the Snowdon mineralization, a back-arc-related rift, is typical of VMS deposits (Hannington et al., 2005). Submarine calderas are especially prospective ore-forming environments (Ohmoto, 1996; Stix et al., 2003; Franklin et al. 2005). The sub-surface magma reservoir inferred to have underlain the Snowdon graben, would have provided a significant source of heat and magmatic volatiles. Extensive faulting and thick pyroclastic deposits associated with the caldera would have produced both structurally-related and stratigraphic permeability that would have facilitated fluid circulation (e.g. Gibson et al. 1999; Stix et al. 2003). The combination of trapdoor subsidence, extensive uplift and differential movement led to the reactivation of existing structures and the creation of new fracture systems to accommodate hydrothermal fluid flow.

In caldera settings the distribution of mineralization may be indicative of an association with a specific stage in the caldera cycle. VMS deposits are most likely to develop during and following caldera collapse and in the course of caldera resurgence (Stix et al. 2003). The LRTF caldera experienced collapse following cessation of the main LRTF eruptions, then resurgence accompanying the intrusion of rhyolites (Howells et al., 1991). Such a change in structural regime may cause the focus of mineralization to move from the caldera's outer faults to the centre of the caldera (Stix et al., 2003). Arcuate structures also frequently develop in caldera environments (Kennedy et al., 2004). The intersection of linear and arcuate structures improves permeability and potentially promotes hydrothermal circulation (Schulz, 2012). Within the LRTF caldera, the concentration of mineralization along an arcuate central corridor (Fig. 1), suggests it was principally associated with caldera resurgence, which led to reactivation of existing structures and the opening of normal faults, the emplacement of the B1 rhyolites, which are abundant within this central zone (Figs. 1 and 3), and 
the early stages of deposition of the BPF. It is notable that the main phase of sulfide mineralization occurred after emplacement of the LRTF, a major, syn-rift felsic unit. In a number of VMS districts globally, the main phase of sulfide deposition occurs in the upper part of felsic units, after which there is also commonly a major change in the composition and style of volcanism (Allen and Weihed, 2002).

The orientation of the major faults and some Snowdon veins (Fig. 1), particularly those within the central part of the Beddgelert Fracture Zone that are near parallel to the graben axis, is consistent with observations from modern graben systems, in which the direction of least principal stress controls the orientation of synvolcanic faults (Franklin et al., 2005). However, Franklin et al. (2005) indicate that in transtensional regimes, such as North Wales (Kokelaar, 1992), extensional faults form oblique to the rift axis. Those faults and mineralized structures that are not parallel to the axis of the Snowdon graben potentially formed after a change to a transtensional structural regime.

With respect to the five-fold classification of VMS deposits proposed by Barrie and Hannington (1999), and developed by Franklin et al. (2005), the Snowdon mineralization most closely resembles the bimodal-felsic lithostratigraphic type (i.e. Kuroko-type VMS deposits), with host volcanic rocks ranging in facies from massive lava flows and domes to volcaniclastic. The Iheya North hydrothermal field in the Okinawa Trough back-arc basin, Japan is a modern analogue for a bimodal-felsic system formed in a continental back-arc (Yeats et al. 2017). The Snowdon mineralization is preferentially developed in coarse, poorly-sorted (proximal or near vent facies) volcaniclastic rocks and brecciated rhyolite facies that formed from volcanic activity and caldera-related tectonic movements. This mechanical brecciation which enhanced permeability, was followed by hydraulic fracturing by high pressure fluids creating sites to accommodate mineralization, as at Hafod y Porth (Figs. 4D and 5A).

\subsection{Petrochemistry of the host rocks}

Felsic igneous rocks associated with the Snowdon Volcanic Centre typically range from dacite to rhyolite, to transitional rhyolite-comendite/pantellerite (Howells et al. 1991). A similar trend is observed in the felsic rocks from the Avoca district in Ireland (McConnell et al. 1991; Lentz, 1998), and also in VMS prospective rocks to the north of the Iapetus Suture (Hollis et al., 2014). The Snowdon felsic rocks have subalkalic to peralkalic within-plate signatures comparable with those of felsic rocks associated with the Avoca, Parys Mountain and Cae Coch VMS deposits (Fig. 12A).

Four suites of felsic volcanic rocks (FI to FIV) have been defined on the basis of their immobile trace-element signatures (Lesher et al. 1986; Hart et al. 2004) (Fig. 12B). Felsic rocks associated with Palaeozoic VMS deposits mainly have FII and FIII signatures (Hart et al., 2004; Piercey, 2011). Felsic rocks associated with the Snowdon Volcanic Centre generally plot near the margin of the FII suite (Fig. 12B), and have similar composition to FII felsic volcanic rocks, with respect to their contents of $\mathrm{SiO}_{2}$ and $\mathrm{TiO}_{2}$, and their $\mathrm{Zr} / \mathrm{Y}$ ratio (Appendix $\mathrm{A}$ ). However, the $\mathrm{Yb}$ contents of the $\mathrm{B} 3$ rhyolites of the 
Snowdon Volcanic Centre and the Avoca felsic rocks are notably higher, plotting close to the FIIIb field of Hart et al. (2004). FIII felsic volcanic rocks are interpreted to result from high temperature melting at shallow levels within the crust. There is a well-established association between this type of magmatism and VMS deposit formation (Piercey, 2011).

In terms of $\mathrm{Y}$ contents and $\mathrm{Zr} / \mathrm{Y}$ ratio the felsic rocks associated with the Snowdon Volcanic Centre broadly coincide with the fields defined by Lentz (1998) for other 'Phanerozoic mineralized sequences' (Fig. 12C). However, in common with rhyolites from the Parys Mountain and Cae Coch VMS deposits, some felsic rocks from the Snowdon Volcanic Centre have higher Y concentrations (at $\mathrm{Zr} / \mathrm{Y}$ ratios of $<5$ ) than in other 'Phanerozoic mineralized sequences'.

The Snowdon rhyolites are characterised by gently to moderately sloping chondrite-normalized REE patterns $\left(\mathrm{La} / \mathrm{Yb}_{\mathrm{n}}=2.7-9.4\right)$, and moderately negative Eu anomalies (mean $\left.\mathrm{Eu} / \mathrm{Eu}^{*}=0.30\right)$ (Fig. 12D). Such slopes are typical of FII to FIII felsic volcanic rocks (Lesher et al. 1986; Hart et al., 2004). The Avoca and Parys Mountain rhyolites exhibit similar patterns and negative Eu anomalies (Fig. 12D). Negative Eu anomalies have been linked to plagioclase fractionation (Lesher et al. 1986; Campbell et al. 1981) in subvolcanic magma chambers, potentially capable of driving VMS associated hydrothermal systems (Lentz 1998).

\subsection{Form of the mineralization}

Discordant vein-type sulfide mineralization typifies the subsurface portion of VMS systems (Nehlig et al. 1997; Franklin et al. 2005). The sulfide-bearing veins and mineralized breccias in the Snowdon area are comparable to the pipelike feeder zones and pyrite-chalcopyrite-quartz vein stockworks found beneath VMS deposits, with classic examples from the Kuroko, Noranda, and Rio Tinto areas of Japan, Canada, and Spain, respectively (Franklin et al. 1981; Nehlig et al. 1997; Galley et al. 2007). Host rocks to these vein systems are typically pervasively altered with abundant Fe-rich chlorite and quartz (Grenne, 1989), a feature also found in the Snowdon area.

\subsection{Geochemical signature of the mineralization}

Copper is the dominant base metal in the Snowdon quartz-sulfide veins, with lesser zinc and lead. In contrast, VMS deposits in bimodal-felsic settings tend to be enriched in zinc and lead relative to copper (Franklin et al. 2005). However, the copper-rich nature of the Snowdon quartz-sulfide veins is also consistent with them representing the chalcopyrite-pyrite veins, which typically underlie bimodal-felsic VMS deposits (Galley et al. 2007) (section 9.4.). Nevertheless, a potential association between the elevated copper contents and the abundant mafic rocks (which reach up to $450 \mathrm{~m}$ thick in the caldera, Fig. 2), in which copper-rich volcanogenic deposits preferentially develop (Barrie and Hannington, 1999; Galley et al. 2007), cannot be excluded. At Parys Mountain, ramifying quartzpyrite-chalcopyrite veins within shales (termed the 'Northern Copper Zone') are interpreted to 
represent a stockwork zone to the VMS deposit (Barrett et al. 2001). Based on data summarised by Micon (2012), these veins typically have higher copper but lower lead and zinc contents than the Snowdon sulfide veins (Fig. 13). Siliceous vein-type mineralization at the Avoca deposit has similar mean copper grades but lower lead and higher zinc values (Moon and Hale, 1983). Base metal concentrations in the Cae Coch, pyrite dominated ore are substantially lower than in the Snowdon quartz-sulfide veins and VMS deposits generally.

The Snowdon quartz-sulfide mineralization is notable for its anomalous bismuth concentrations, due to the presence of bismuthinite and native bismuth (section 5.0.). Elevated cobalt levels reflect the occurrence of trace cobaltite in the Snowdon mineralization (Fig. 13). Enrichment in bismuth and copper, with elevated cobalt are consistent with a felsic magmatic source for these metals (Franklin et al. 2005).

Median arsenic concentrations are similar to those at Cae Coch and Avoca, but significantly lower than at the Brunswick No. 12 VMS deposit (Fig. 13). Nickel contents of the Snowdon veins are generally low and consistent with VMS deposits globally. Molybdenum contents of the Snowdon quartz-sulfide veins are much lower than in the Cae Coch deposit, but are similar to those reported for the Brunswick No. 12 deposit. In common with Cae Coch $(<100$ ppm Sn; Ball and Bland, 1985) the tin content of the Snowdon quartz-sulfide veins is considerably lower than in the Brunswick No. 12 deposit (Fig. 13).

Mean gold and silver contents of the Snowdon quartz-sulfide veins are lower than the global average values for 'early Phanerozoic' VMS deposits of the bimodal-felsic class (Barrie and Hannington, 1999). Compared to the shale-hosted veins of the Northern Copper Zone at Parys Mountain the Snowdon veins have lower mean Au, but higher mean Ag contents. Rarely VMS deposits have gold contents lower than the Snowdon veins, for example, the Stirling deposit (0.03 ppm $\mathrm{Au}$ ), hosted in a sequence of bimodal volcaniclastic rocks, in the Avalon Zone of the Canadian Appalachians (Kontak, 1999).

The fluorine content (mean $>1000 \mathrm{ppm}$ ) of the Snowdon quartz-sulfide veins and their immediate host rocks is anomalously high (average reported F concentrations for felsic volcanic rocks globally range from 285-790 ppm; Lavery, 1985). The high fluorine in the Snowdon area is consistent with observations from some altered felsic volcanic rocks hosting VMS deposits (e.g. Lavery, 1985; Koopman et al. 1999; Hannington et al. 2003).

\subsection{Sulfur isotopes - local influences and global context}

Potential sources of sulfur for mineralization formed in submarine volcanic environments include sulfur contained in the country rocks, both igneous and sedimentary; magmatic sulfur; and seawater sulfate (Huston, 1999). The mean $\delta^{34} \mathrm{~S}$ signature $(+13.0 \%$ $\pm 3.4 \%$ ) of vein sulfide in this area falls well outside that expected for magmatic sulfur, typically -3 to $+5 \%$ (Ohmoto, 1986), and 
indicates input from a source enriched in $\delta^{34} \mathrm{~S}$. Disseminated sulfide in unmineralized tuffs and rhyolites of the SVG, has a range and mean $\delta^{34} \mathrm{~S}$ of $11.7 \pm 4.5 \%$ (Fig. 10B), which is statistically indistinguishable from that of the mineralized system (Fig. 10A). In north-eastern Snowdonia, in the vicinity of the Cae Coch pyrite deposit, dolerite bodies thought to be directly related to the Ordovician volcanic activity (Howells et al., 1991) record $\delta^{34} \mathrm{~S}$ values from +0.2 to $+11.1 \%$ (Bottrell and Morton, 1992). However, $\delta^{34} \mathrm{~S}$ signatures for pyrite from the Cae Coch deposit range from -24 to $-4 \%$, clustering between -24 and $-20 \%$. These signatures are considerably lighter than those observed in the Snowdon mineralization as well as Ordovician VMS deposits generally. A model for the Cae Coch deposit invokes bacterial sulfate reduction in the sediments as the principal source of sulfide sulfur (Bottrell and Morton, 1992), clearly not a feature seen in the Snowdon system.

The spread of the country rock values in the SVG and the limited number of samples analysed (Fig. 10B) make it difficult to constrain the sulfur reservoir to a specific formation, however, there is little doubt that the sulfur in the veins was either derived by the same mechanism as the disseminated country rock sulfides, or was leached from the sequence. Conceptually, the large scale hydrothermal system envisaged for the Snowdon caldera (Reedman et al. 1985; Ball and Colman, 1998) is likely to have interacted with the country rocks, over several kilometres, vertically and laterally. In such a system, it is easy to envisage the incorporation of leached sulfide sulfur into the hydrothermal fluids, to generate the observed $\delta^{34} \mathrm{~S}$ signatures (Fig. 10A).

Published isotope data for the Parys Mountain deposit are limited (Fig. 14). Work by Leys et al. (1990) identifies a narrow range of $\delta^{34} \mathrm{~S}$ signatures, ranging from $+8.6 \%$ to $+14.1 \%$. Subsequent work by Chopey-Jones et al. (2004) suggests a greater range of $\delta^{34} \mathrm{~S}$ signatures. Samples from the Carreg-yDol zone, which consists of massive quartz-rich rocks and chalcopyrite-pyrite-rich veins and metersize pods of semi-massive sulfide (Barrett et al. 2001) range from $-9 \%$ to $+16 \%$ (mean $=+10 \%$ ) (Chopey-Jones et al. 2004). $\delta^{34} \mathrm{~S}$ signatures for samples from the western end of the deposit, comprising quartz-rich rocks and semi-massive sulfides (Barrett et al. 2001) range from $+3 \%$ to $+17 \%$ (mean $=+12 \%$ ).$\delta^{34} \mathrm{~S}$ signatures for pyrite from the central shales/stockwork range from $+12 \%$ to $+18 \%$ o $($ mean $=+14 \%$ ) (Chopey-Jones et al. 2004). Chopey-Jones et al. (2004) conclude that the sulfide in the hydrothermal system at Parys Mountain is likely to be derived from reduction of coeval seawater sulfate. Sulfur isotope analyses indicate no distinction between the different styles of mineralization at Avoca, with $\delta^{34} \mathrm{~S}$ values typically ranging from $+6.8 \%$ to $+12.3 \%$. Samples from a mineralized rhyolite at Avoca have a wider range of $+0.2 \%$ to $+17.4 \%$. It has been proposed that the sulfur in the deposit was derived from a combination of magmatic and seawater sources (Williams et al. 1986).

Average $\delta^{34}$ S signatures of sulphides from Phanerozoic VMS deposits globally are variable, with Ordovician deposits typically ranging from $-5.0 \%$ to $+20.7 \%$ (Huston, 1999). With the exception of a single analysis, the $\delta^{34} \mathrm{~S}$ signatures for the mineralization around Snowdon fall within this range. The $\delta^{34} \mathrm{~S}$ signatures obtained for the Snowdon veins are also compatible with the observation of 
Sangster et al. (1968), which indicates that on average the $\delta^{34} \mathrm{~S}$ signature of seawater sulfate is $+17.5 \pm$ 2.5\% greater than that of the sulfide minerals in VMS deposits (Fig. 14).

The world class VMS deposits of the Bathurst Mining Camp in the Canadian Appalachians occur in a comparable middle Ordovician bimodal volcanic and sedimentary sequence, formed within an arc and continental back-arc environment (Goodfellow et al. 2003). $\delta^{34} \mathrm{~S}$ signatures for sulfide minerals from the Brunswick No. 12 deposit range from $+7.9 \%$ to $+18.3 \%$ (mean $=+14.2 \%$ ) in the 'bedded ore' (massive pyrite interlayered with sphalerite, galena, minor chalcopyrite and pyrrhotite); $+11.9 \%$ to $+18.4 \%$ o (mean $=+15.8 \%$ o) in the 'vent complex' (massive sulfide consisting of pyrite and pyrrhotite, with variable chalcopyrite and magnetite content, formed by brecciation, infilling and veining of the bedded ore); and $+13.9 \%$ to $+18.8 \%$ (mean $=+16.1 \%$ ) in the 'stockwork' or feeder zone (Goodfellow and Peter, 1996). Studies on modern hydrothermal systems suggest that reduction of Ordovician seawater sulfate ( $\sim 28 \%$, Claypool et al. 1980$)$, in the presence of ferrous silicates and magnetite (Janecky and Shanks, 1988), such as locally found around Snowdon, can result in $\delta^{34} \mathrm{~S}$ signatures $\geq 8 \%$. On balance, whilst a limited contribution of magmatic sulfur cannot be ruled out, it would appear ultimately that thermochemical reduction of contemporaneous Ordovician seawater sulfate was the dominant mechanism for sulfide production in the Snowdon system.

\subsection{A volcanogenic massive sulfide-type system?}

Although many features of the Snowdon quartz-sulfide vein system and host geological environment are similar to those of classic VMS deposits (Table 3), no strata-bound sulfide accumulations have been found to date, despite commercial exploration drilling. Nonetheless, the possibility remains that the Snowdon veins represent the stockwork of a hydrothermal system that for some reason failed to produce a sulfide deposit on the seafloor. In Australia, some volcanic-hosted polymetallic sulfide deposits have little or no obvious association with strata-bound mineralization. These copper-rich deposits take the form of discordant, structurally controlled, pyrite-chalcopyriterich pipes or disseminated and stringer-style mineralization. The pipes typically comprise sulfide-rich breccias and quartz-sulfide veins, and are enriched in trace elements including Bi and Mo, and locally contain minor magnetite (Large, 1992). Such features also are common in the Snowdon vein systems. At some of the Australian deposits, synvolcanic growth faults are thought to have controlled fluid flow and the location and geometry of the sulfide mineralization (Gemmell et al. 1998). The Bawdin polymetallic sulfide deposit in Myanmar also consists of sub-vertical pipes in rhyolitic volcaniclastic rocks, but is similar in terms of mineralogy, alteration and metal zonation to VMS systems (Zaw, 2003). The Baiyinchang deposit in China is dominated by a discordant sulfide-rich zone, comprising a variety of ore types, ranging from unbanded, massive sulfide to chalcopyrite-rich stringer veins (Zengqian et al. 2008). On Cyprus, lenticular bodies of massive sulfide are underlain by pipe-shaped zones of stockwork sulfide mineralization, hosted by mafic lavas (Hutchinson and Searle, 1971). The stockwork veins, which consist of pyrite \pm chalcopyrite and sphalerite-bearing quartz, surround 
pillows, and fill interstices between pillows and within brecciated lavas. Similar veins are seen within the mafic sequence at Lliwedd in the Snowdon Caldera (Fig. 6C). In the upper parts of the Cyprus stockworks, the sulfide veins typically broaden and merge to create irregular pods of almost massive sulfide (Hutchinson and Searle, 1971). This is also reminiscent of some of the mineralized zones around Snowdon. According to Large (1992), a continuum exists between pipe-style, stockwork type sulfide mineralization, and mounds or lenses of massive sulfides.

\subsection{Seafloor environment and failure to develop strata-bound mineralization}

The Snowdon Caldera developed in a shallow-water setting (Howells et al. 1986), in contrast to the deep water (Howells et al. 1991), low energy, sedimentary environment in which the Cae Coch pyrite deposit in north-east Snowdonia formed (Ball and Bland, 1985), and the deep-water volcanic setting of many major VMS-hosting districts globally (Hannington et al. 2005). Shallow water depths and associated low hydrostatic pressures will generally promote subseafloor boiling and the development of stockwork mineralization, as opposed to the accumulation of massive sulfide deposits on the deep seafloor (Drummond and Ohmoto, 1985; Cas, 1992). In fact, Ohmoto and Takahashi (1983) proposed that a minimum seawater depth of $1000 \mathrm{~m}$ is essential to prevent boiling of hydrothermal fluids, and an associated drop in temperature, and $\mathrm{pH}$ that would induce sulfide precipitation, and form disseminated or vein-style deposits. As a result of the deformation in Snowdonia, which has destroyed the primary fluid inclusions, it is not possible to determine if boiling was responsible for deposition of the Snowdon vein sulfides. Despite a lack of conclusive evidence for boiling, the style and textures of the mineralization at Snowdon closely resemble those observed at the Little Deer Deposit in Newfoundland, Canada where disseminated and stringer-type mineralization are present, but no massive sulfide mound (Toman, 2012). According to Toman (2012), boiling of fluids caused brecciation of the host rocks and deposition of $\mathrm{Cu}$-rich veins. The correlation between silver and antimony in the Snowdon quartz-sulfide veins suggests Ag may be associated with sulfosalts, which are particularly common in VMS deposits associated with felsic rocks (Taylor et al 1996; Hollis et al. 2017). The low temperature, sulfosalt assemblage at the Eskay Creek VMS deposits is attributed to subsurface boiling of the hydrothermal fluids in a relatively shallow-water environment (Sherlock et al. 1999).

Massive sulfide deposits require time for accumulation on or close to the seafloor during periods of tectonic stability (Franklin, 1986; Gibson et al. 1999). Periods of quiescence are especially important in proximal volcanic environments, such as Snowdon, as volcanism will otherwise potentially disrupt or halt hydrothermal discharge (Gibson et al. 1999). At Avoca, where mineralization is associated with the peak period of volcanism, stratiform ores only developed during periods of reduced volcanic activity (Pointon, 1980). At Pary's Mountain the volcanic rocks almost directly overlie the main massive sulfide horizon (Barrett et al. 2001), and probably terminated the 
deposition of the massive sulfides (Personal communication). At Snowdon, there is no evidence for periods of volcanic quiescence during development of the LRTF caldera and subsequent deposition of the BPF. Rather, volcaniclastic material was supplied at catastrophic rates to a high energy, shallow water marine environment (Fig. 15). This is evident from the slumping and extensive reworking of the volcaniclastic deposits as described by Howell et al. (1991), and the mineralized fragments contained within the volcanic pile (Figs. 4B, 6E). Such an environmental setting is not conducive to the accumulation of sulfide mineralization at or near the seafloor, and as has been suggested for Avoca, could have resulted in the destruction of any bedded sulfide ore (Pointon, 1980).

Protracted hydrothermal activity, driven by sustained heatflow associated with a long-lived, but not highly dynamic magmatic centre, is considered an important control on the development of VMS deposits (Bleeker and Parrish, 1996; Piercey, 2011). A number of geochronological studies illustrate a relationship between prolonged magmatism and VMS formation (e.g. Bleeker and Parrish, 1996; Galley et al. 2000; Galley and van Breemen, 2002; Piercey et al. 2008). In these studies, the duration of magmatism ranges from 3-14 Ma. At Snowdon, by contrast, the SVG was deposited over a maximum interval of $1 \mathrm{Ma}$, which limits the duration of the hydrothermal system to about $1 \mathrm{Ma}$.

In addition, there is no evidence that large intrusions were present directly under the SVG during its formation. Rather, a number of small, short-lived, high-level magma chambers may have existed (Thorpe et al. 1993), not necessarily all at the same time. These small intrusions, when combined with rapid convective cooling of the highly permeable volcanic pile (e.g. Cathles et al. 1997), may not have provided enough total heat at any one time to generate a major hydrothermal system capable of producing sizable massive sulfide deposits on the seafloor, particularly if large volumes of volcanic debris frequently inundated the shallow marine setting.

\section{Conclusions}

Mineralization in the Snowdon Volcanic Centre is hosted by Ordovician bimodal volcanic rocks forming part of the ensialic backarc sequence of the Avalon Zone of the British and Irish Caledonides. It comprises discordant base metal sulfide-bearing veins and stockworks, mineralized breccias, disseminated sulfides and localized zones of semi-massive/massive sulfide, with subordinate magnetite-rich veins. Based on field relationships, sulfur isotopes, new dating of the host volcanic rocks, and compilation of legacy data we conclude that the mineralization is intimately related to caldera volcanism, with the metals mainly derived from the host volcanic sequence, and the sulfur from seawater (although a small magmatic contribution of $\mathrm{S}$ cannot be discounted). Sulfide deposition principally occurred during caldera resurgence and an associated transition to basaltic dominated volcanism, and the emplacement of high-level rhyolites. It is interpreted to represent both wellfocused hydrothermal fluids moving along major fracture zones and caldera-related faults, during this period of repeated extension and fault reactivation, and simultaneous dispersal of mineralizing fluids 
through the rapidly accumulating, unstable and highly permeable volcaniclastic pile. The overall structural and stratigraphic setting, the intimate association with bimodal magmatism, the mineralogy, geochemistry, alteration patterns and sulfur isotope data suggest that the Snowdon sulfide occurrences represent volcanogenic, structurally controlled, vein-type to semi-massive, pipe-style polymetallic sulfide mineralization. It is possible that this vein, disseminated and stockwork style mineralization represents feeder zones to strata-bound ores that remain undiscovered and/or have been removed by recent erosion, but more likely never developed due to the unsuitable marine environment.

The well constrained evolution of the Snowdon caldera and unequivocal sedimentological evidence for water depth and paleoenvironment makes it an excellent location to study the influence of local environment on the character of the associated mineralization. Despite the fertile tectonic and magmatic environment and many other favourable VMS formation criteria, strata-bound sulfide ores, precipitated at or near the seafloor, which typify these deposits are absent. This is attributed to:

1. Very shallow water depths and, hence low hydrostatic pressure, which promoted boiling and the formation of subseafloor stockwork type mineralization;

2. Tectonic instability of the caldera and catastrophic rates of volcaniclastic material supply, coupled with a high energy and destructive marine environment, which would have disrupted and destroyed sulfides potentially accumulating at or near to the seafloor (Fig. 15); and

3. A highly dynamic and short-lived period of magmatism, insufficient to drive the protracted hydrothermal circulation generally considered necessary to form large massive sulfide deposits.

This study further demonstrates that, whilst structurally complex and thermally anomalous environments, that have driven significant hydrothermal circulation, such as the Snowdon caldera, may appear highly prospective for VMS deposits, careful paleoenvironmental interpretation is required to determine true mineral exploration potential. Whilst reliably establishing the paleoenvironmental conditions prevailing during the deposition of ancient, deformed volcanic successions is time consuming and challenging, detailed facies mapping and paleoenvironmental reconstruction, including water depth assessments should be a priority in VMS exploration programs.

The absence of VMS mineralization associated with the Snowdon Centre is consistent with the view of Hollis et al. (2014) that the Avalon Zone appears to represent the least prospective part of the British and Irish Caledonides. However, the assertion that adjacent Ganderian crust in the British Isles is more prospective, is based upon only two known VMS deposits (Parys Mountain and Avoca), and the relative lack of identified economic VMS mineralization in the Avalon Zone. This may be an artefact of limited exploration of these rocks in the British Isles, particularly in the context of modern understanding of VMS deposit formation. Failure of the Snowdon hydrothermal system to produce a VMS deposit appears to principally be the result of the nature of the magmatic system and local depositional environment rather than an inherent deficiency resulting from its location on Avalonian basement. Accordingly, other submarine bimodal volcanic sequences, and ideally those resulting from 
longer-lived, but not overly dynamic magmatic centres, which have subsequently experienced rapid extension and subsidence to deep marine environments should be the priority targets for future exploration in North Wales. The later conditions are exemplified in the Avalon Zone of the British Caledonides by the Crafnant Basin in north-east Snowdonia, where a stratiform pyrite body is preserved.

951

\section{Acknowledgements}

PL, AL, and IM publish with the permission of the Executive Director, British Geological Survey (NERC). The M.Sc. students Anthony Jacobs, Jonathan Hodgins and Phillip Stevenson, from the University of Exeter are thanked for their contribution to the study. Tim Colman made a very valuable contribution to the research project, particularly the provision of legacy data and his involvement in the fieldwork program. Ian Mounteney separated the sulfides for the conventional S isotope analyses. Steve Piercey is thanked for his advice and providing information. Gus Gunn and Tim Barrett greatly contributed to improving the manuscript. Our gratitude is further expressed to Prof. Franco Pirajno, Steve Hollis and an anonymous reviewer for reviewing the manuscript and making valuable comments and suggestions. BGSC NERC 2017. All rights reserved.

\section{References}

964

965

966
Allen, R. L., and Weihed, P., 2002, Global comparisons of volcanic-associated massive sulphide districts: Geological Society, London, Special Publications, v. 204, p. 13-37.

Anglesey Mining, 2015, Parys Mountain Mineral Resource estimate at $\$ 80$ per tonne GMPV Cut-Off (http://angleseymining.co.uk/projects/parysresources.html).

Ball, T. K., and Bland, D. J., 1985, The Cae Coch volcanogenic massive sulphide deposit, Trefriw, North Wales: Journal of the Geological Society, v. 142, p. 889-898.

Ball, T. K., and Colman, T. B., 1998, Geochemistry of caldera and wallrock alteration associated with volcanogenic sulphide vein mineralization, Snowdon, North Wales: Transactions Institute Mining Metallurgy (Sect. B: Appl. earth sci.), v. 107, p. 63-75.

Barrett, T. J., MacLean, W.H., Tennant, W.C., 2001, Volcanic sequence and alteration at the Parys Mountain volcanic-hosted massive sulfide deposit, Wales, United Kingdom: applications of immobile element lithogeochemistry: Economic Geology, v. 96, p. 1279-1305.

Barrie, C. T., and Hannington, M.D., 1999, Classification of volcanic-associated massive sulfide deposits based on host rock composition: Reviews in Economic Geology v. 8, p. 1-11.

Bleeker, W., and Parrish, R. R., 1996, Stratigraphy and U - Pb zircon geochronology of Kidd Creek: implications for the formation of giant volcanogenic massive sulphide deposits and the 
1001

1002

1003

1004

1005

1006

1007

1008

1009

1010

1011

1012

1013

1014

1015

1016 tectonic history of the Abitibi greenstone belt: Canadian Journal of Earth Sciences, v. 33, p. 1213-1231.

Bottrell, S. H., Morton, M. D. B., 1992, A reinterpretation of the genesis of the Cae Coch pyrite deposit, North Wales: Journal of the Geological Society, v. 149, p. 581-584.

Brown, M. J, and Evans, A. D., 1989, Geophysical and geochemical investigation of the manganese deposits of the Rhiw, western Llyn, North Wales: British Geological Survey Technical Report $\mathrm{WF} / 89 / 14,84 \mathrm{p}$.

British Geological Survey, 2013, Digital Geological Map of Great Britain 1:50 000 scale (DiGMapGB-50) data, Version 7.22. Keyworth, Nottingham: British Geological Survey. Tile EW119_Snowdon. Release date 15-04-2013. DOI 10.5285/33054628-1276-4487-b9bdcd5faa8a395c

Campbell, I. H., Franklin, J. M., Gorton, M. P., Hart, T. R., and Scott, S. D., 1981, The role of subvolcanic sills in the generation of massive sulfide deposits: Economic Geology, v. 76, p. 2248-2253.

Campbell, S. D. G., Reedman, A. J., and Howells, M. F., 1985, Regional variations in cleavage and fold development in North Wales: Geological Journal, v. 20, p. 43-52.

Campbell, S. D. G., Howells, M. F., Smith, M., and Reedman, A. J., 1988, A Caradoc failed-rift within the Ordovician marginal basin of Wales: Geological Magazine, v. 125, p. 257-266.

Campbell, S. D. G., Reedman, A. J., Howells, M. F., and Mann, A. C., 1987, The emplacement of geochemically distinct groups of rhyolites during the evolution of the lower rhyolitic tuff formation caldera (Ordovician), North Wales, U.K: Geological Magazine, v. 124, p. 501-511.

Cas, R. A. F., 1992, Submarine volcanism; eruption styles, products, and relevance to understanding the host-rock successions to volcanic-hosted massive sulfide deposits: Economic Geology, v. 87 , p. 511-541.

Cathles, L. M., Erendi, A. H. J., and Barrie, T., 1997, How long can a hydrothermal system be sustained by a single intrusive event?: Economic Geology, v. 92, p. 766-771.

Chopey-Jones, A. M., Jenkin, G.R.T, Zalasiewicz, J., and Boyce, A.J., 2004, Sulphur isotopes and fluid inclusions as constraints on the timing of mineralization at the Parys Mountain VMS deposit, Anglesey, Wales: MDSG 27th Annual Winter Meeting, Leeds, Jan 2004, Leeds, 2004.

Claypool, G. E., Holser, W. T., Kaplan, I. R., Sakai, H., and Zak, I., 1980, The age curves of sulfur and oxygen isotopes in marine sulfate and their mutual interpretation: Chemical Geology, v. 28, p. 199-260.

Colman, T. B., and Appleby, A. K., 1991, Volcanogenic quartz-magnetite-hematite veins, Snowdon, North Wales: Mineralogical Magazine, v. 55, p. 257-262.

Cooper, D. C., and Colman, T. B., 2000, Exploration for metalliferous and related minerals in Britain: a guide: British Geological Survey DTI Minerals Programme Publication No. 1, 78 p. 
Drummond, S. E., and Ohmoto, H., 1985, Chemical evolution and mineral deposition in boiling hydrothermal systems: Economic Geology, v. 80, p. 126-147.

Elston, W. E., 1994, Siliceous volcanic centers as guides to mineral exploration: review and summary: Economic Geology, v. 89, p. 1662-1686.

Evans, J. A., 1990, Resetting of the Rb-Sr whole-rock system of an Orodvician microgranite during low-grade metamorphism: Geological Magazine, v. 126, p. 675-679.

Franklin, J. M., Gibson, H.L., Jonasson, I.R. and Galley, A.G., 2005, Volcanogenic massive sulfide deposits: Economic Geology One Hundreth Anniversary Volume, p. 523-560.

Franklin, J. M., Lydon, J.W. and Sangster, D.F., 1981, Volcanic-associated massive sulfide deposits: Economic Geology $75^{\text {th }}$ anniversary volume, p. 485-626.

Galley, A., and van B Breeman, O., 2002, Timing of synvolcanic magmatism in relation to base-metal mineralization, Rouyn-Noranda, Abitibi volcanic belt, Quebec: Geological Survey of Canada Current Research Report 2002-F8, 9 p.

Galley, A., van Breemen, O., and Franklin, J., 2000, The relationship between intrusion-hosted CuMo mineralization and the VMS deposits of the Archean Sturgeon Lake Mining Camp, Northwestern Ontario: Economic Geology, v. 95, p. 1543-1550.

Galley, A. G., Hannington, M. D., and Jonasson, I. R., 2007, Volcanogenic massive sulphide deposits: Geological Association of Canada Special Publication No. 5, p. 141-161.

Gemmell, J. B., Large, R. R., and Zaw, K., 1998, Palaeozoic volcanic-hosted massive sulphide deposits: AGSO Journal of Australian Geology \& Geophysics, v. 17, p. 129-137.

Gibson, H.L., Morton, R.L., and Hudak, G.J., 1999, Submarine volcanic processes, deposits, and environments favorable for the location of volcanic associated massive sulfide deposits: Reviews in Economic Geology v. 8, p.13-51.

Goodfellow, W. D., and Peter, J. M., 1996, Sulphur isotope composition of the Brunswick No. 12 massive sulphide deposit, Bathurst Mining Camp, New Brunswick: implications for ambient environment, sulphur source, and ore genesis: Canadian Journal of Earth Sciences, v. 33, p. 231-251.

Goodfellow, W. D., McCutcheon, S.R., and Peter, J.M., 2003, Massive sulfide deposits of the Bathurst Mining Camp, New Brunswick, and Northern Maine: Economic Geology Monograph 11, p. 1-16.

Grenne, T., 1989, The feeder zone to the Lokken ophiolite-hosted massive sulfide deposit and related mineralizations in the central Norwegian Caledonides: Economic Geology, v. 84, p. 21732195.

Guillou-Frottier, L., Burov, E. B., and Milési, J. P., 2000, Genetic links between ash-flow calderas and associated ore deposits as revealed by large-scale thermo-mechanical modeling: Journal of Volcanology and Geothermal Research, v. 102, p. 339-361. 
Hannington, M. D., Kjarsgaad, I. M., Galley, A. G., and Taylor, B, 2003, Mineral-chemical studies of metamorphosed hydrothermal alteration in the Kristineberg volcanogenic massive sulfide district, Sweden: Mineralium Deposita, v. 38, 423-442.

Hannington, M. D., de Ronde, C.E.J., and Petersen, S, 2005, Sea-floor tectonics and submarine hydrothermal systems: Economic Geology One Hundreth Anniversary Volume, p. 111-141.

Hart, T. R., Gibson, H. L., and Lesher, C. M., 2004, Trace element geochemistry and petrogensis of felsic volcanic rocks associated with volcanogenic massive $\mathrm{Cu}-\mathrm{Zn}-\mathrm{Pb}$ sulfide deposits: Economic Geology, v. 99, p. 1003-1013.

Hodgins, J. K., 2009, An investigation into the sulphide mineralisation and associated alteration within the Snowdon Apical Graben, North Wales; the Lliwedd mine: Unpublished M.Sc. thesis, Exeter, UK, University of Exeter, p. 114.

Hollis, S. P, Roberts, S., Earls, G., Herrington, R., Cooper, M, R., Piercey, S. J., Archibold, S. M., and Moloney, M., 2014, Petrochemistry and hydrothermal alteration within the Tyrone Igneous Complex, Northern Ireland: implications for VMS mineralization in the British and Irish Caledonides: Mineralium Deposita, v. 49, p. 575-593.

Hollis, S. P., Mole, D. R., Gillespie, P., Barnes, S. J., Tessalina, S., Cas, R. A. F., Hildrew, C., Pumphrey, A., Goodz, M. D., Caruso, S., Yeats, C. J., Verbeeten, A, Belford, S, M., Wyche, S., and Martin, L. A. J., 2017, 2.7 Ga plume associated VHMS mineralization in the Eastern Goldfields Superterrane, Yilgarn Craton: insights from the low temperature and shallow water, Ag-Zn-(Au) Nimbus deposit: Precambrian Research, v. 289, p. 119-142.

Howells, M. F., Reedman, A. J., and Campbell, S. D. G., 1986, The submarine eruption and emplacement of the Lower Rhyolitic Tuff Formation (Ordovician), N Wales: Journal of the Geological Society, v. 143, p. 411-423.

Howells, M. F., Reedman, A. J., and Campbell, S.D.G., 1991, Ordovician (Caradoc) marginal basin volcanism in Snowdonia (north-west Wales): London, HMSO for the British Geological Survey, $191 \mathrm{p}$.

Howells, M. F., and Smith, M., 1997, Geology of the Country around Snowdon: London, HMSO for the British Geological Survey, 191 p. 104 p.

Huston, D. L., 1999, Stable isotopes and their significance for understanding the genesis of volcanichosted massive sulfide deposits: a review: Reviews in Economic Geology v. 8, p. 157-180.

Hutchinson, R. W., and Searle, D. L., 1971, Stratabound pyrite deposits in Cyprus and relations to other sulphide ores: Society of Mining Geologists of Japan Special Issue 3, 198-205.

Jaffey, A. H., Flynn, K. F., Glendenin, L. E., Bentley, W. C., and Essling, A. M., 1971, Precision measurement of half-lives and specific of 235U and 238U: Physics Reviews, v. C4, p. 18891906. 
Janecky, D. R., and Shanks, W.C., 1988, Computational modeling of chemical and sulfur isotopic reaction processes in seafloor hydrotherermal systems: chimneys, massive sulfides, and subjacent alteration zones: Canadian Mineralogist, v. 26, p. 805-825.

Kennedy, B., Stix, J., Vallance, J. W., Lavallée, Y., and Longpré, M.A., 2004, Controls on caldera structure: results from analogue sandbox modeling: Geological Society of America Bulletin, v. 116 , p. $515-524$.

Kokelaar, B. P., Howells, M. F., Bevins, R. E., Roach, R. A., and Dunkley, P. N., 1984, The Ordovician marginal basin of Wales: Geological Society, London, Special Publications, v. 16, p. 245-269.

Kokelaar, P., 1988, Tectonic controls of Ordovician arc and marginal basin volcanism in Wales: Journal of the Geological Society, v. 145, p. 759-775.

Kokelaar, P., 1992, Ordovician marine volcanic and sedimentary record of rifting and volcanotectonism: Snowdon, Wales, United Kingdom: Geological Society of America Bulletin, v. 104, p. 1433-1455.

Koopman, E.R., Hannington, M. D., Santaguida, F., Cameron, B.I., 1999, Petrology and geochemistry of proximal hydrothermal alteration at Kidd Creek: Economic Geology Monograph 11, p. 267-296.

Kontak, D. J. 1999. Geochemical profile of a carbonate-quartz alteration zone in footwall rocks of the Stirling VMS base metal deposit, Richmond County, Cape Breton Island: Report of Activities 1998. Report ME 1991-1, Government of Nova Scotia, 25-37.

Koski, R. A., 2012, Hypogene Ore Characteristics in volcanogenic massive sulfide occurrence model: U.S. Geological Survey Scientific Investigations Report 2010-5070-C, p. 137-146.

Jacobs, A., 2008, Characterisation of mineralisation within the Snowdon Apical Graben; the Hafod-yPorth mine workings: Unpublished M.Sc. thesis, Exeter, UK, University of Exeter, p. 104.

Large, R. R., 1992, Australian volcanic-hosted massive sulfide deposits; features, styles, and genetic models: Economic Geology, v. 87, p. 471-510.

Lavery, N. G., 1985, The use of fluorine as a pathfinder for volcanic-hosted massive sulfide ore deposits: Journal of Geochemical Exploration, v. 23, p. 35-60.

Leat, P. T., Jackson, S. E., Thorpe, R. S., and Stillman, C. J., 1986, Geochemistry of bimodal basaltsubalkaline/peralkaline rhyolite provinces within the Southern British Caledonides: Journal of the Geological Society, v. 143, p. 259-273.

Lentz, D. R., 1998, Petrogenetic evolution of felsic volcanic sequences associated with Phanerozoic volcanic-hosted massive sulphide systems: the role of extensional geodynamics: Ore Geology Reviews, v. 12, p. 289-327.

Lesher, C. M., Goodwin, A. M., Campbell, I. H., and Gorton, M. P., 1986, Trace-element geochemistry of ore-associated and barren, felsic metavolcanic rocks in the Superior Province, Canada: Canadian Journal of Earth Sciences, v. 23, p. 222-237. 
Leys, C., Caulfield, J.D.B., Boyce, A.J., and Fallick, A.E., 1990, An overview of the geology and isotope geochemistry of the Anglesey Mine, Parys Mountain, Wales [ab]: Minerals Deposit Studies Group Annual Meeting, Trinity College, Dublin, 1990.

Lipman, P. W., 1992, Ash-Flow Calderas as Structural Controls of Ore Deposits Recent Work and Future Problems: U.S. Geological Survey Bulletin 2012, p. L1-L11.

Mattinson, J. M., 2005, Zircon U-Pb chemical abrasion (“CA-TIMS”) method: combined annealing and multi-step partial dissolution analysis for improved precision and accuracy of zircon ages: Chemical Geology, v. 220, p. 47-66.

Mattinson, J. M., 2010, Analysis of the relative decay constants of $235 \mathrm{U}$ and $238 \mathrm{U}$ by multi-step CATIMS measurements of closed-system natural zircon samples: Chemical Geology, v. 275, p. 186-198.

McClenaghan, S., Lentz, D., Martin, J., and Diegor, W., 2009, Gold in the Brunswick No. 12 volcanogenic massive sulfide deposit, Bathurst Mining Camp, Canada: evidence from bulk ore analysis and laser ablation ICP-MS data on sulfide phases: Mineralium Deposita, v. 44, p. 523-557.

McConnell, B. J., Stillman, C. J., and Hertogen, J. 1991. An Ordovician basalt to peralkaline rhyolite fractionation series form Avoca, Ireland: Journal of the Geological Society, v. 148, p. 711718.

McConnell, B., 1991, Geochemistry and mineralogy of volcanic host rocks as indicators of massive sulphide genesis at Avoca, southeast Ireland: Irish Journal of Earth Sciences, v. 11, p. 43-52.

McDonough, W.F., and Sun, S.S., 1995, Composition of the Earth, Chemical Geology, v. 120, p 223253.

Merriman, J., and Roberts, S. B., 1985, A survey of white mica crystallinity and polytypes in pelitic rocks of Snowdonia and LIfn, North Wales: Mineralogical Magazine, v. 49, p. 305-319.

Micon, 2012, Parys Mountain Resource Estimate, Micon International Co Limited.

Mining Journal, 2010, Land of opportunity, 26 March 2010, p. 22-23.

Moon, C. J., and Hale, M., 1983, Geochemical dispersion patterns of As, Sb, Bi and Se associated with sulfide mineralization at Avoca, Eire: Journal of Geochemical Exploration, v. 19, p. 663677.

Nehlig, P., Cassard, D., and Marcoux, E., 1997, Geometry and genesis of feeder zones of massive sulphide deposits: constraints from the Rio Tinto ore deposit (Spain): Mineralium Deposita, v. 33, p. 137-149.

Ohmoto, H., 1978, Submarine calderas: A key to the formation of volcanogenic massive sulfide deposits: Mining Geology, v. 28, p. 219-231.

Ohmoto, H., 1986, Stable isotope geochemistry of ore deposits, Reviews in Mineralogy and Geochemistry 16, p. 491-559. 
Ohmoto, H., 1996, Formation of volcanogenic massive sulfide deposits: the Kuroko perspective: Ore Geology Reviews, v. 10, p. 135-177.

Ohmoto, H., and Takahashi, T., 1983, Part III. Submarine calderas and Kuroko genesis: Economic Geology Monograph 5, p. 39-54.

Pearce, J. A., Harris, N. B. W., and Tindle, A. G., 1984, Trace element discrimination diagrams for the tectonic interpretation of granitic rocks: Journal of Petrology, v. 25, p. 956-983.

Piercey, S., 2011, The setting, style, and role of magmatism in the formation of volcanogenic massive sulfide deposits: Mineralium Deposita, v. 46, p. 449-471.

Piercey, S. J., Peter, J. M., Mortensen, J. K., Paradis, S., Murphy, D. C., and Tucker, T. L., 2008, Petrology and $\mathrm{U}-\mathrm{Pb}$ geochronology of footwall porphyritic rhyolites from the Wolverine volcanogenic massive sulfide deposit, Yukon, Canada: implications for the genesis of massive sulfide deposits in continental margin environments: Economic Geology, v. 103, p. 5-33.

Pointon, 1980, Some environmental feature of volcanogenic sulphide mineralisation at Avoca, Eire, and Parys Mountain, Anglesey, Wales: Norges geologiske undersøkelse., v. 360, p. 259-268.

Reedman, A. J., Colman, T. B., Campbell, S. D. G., and Howells, M. F., 1985, Volcanogenic mineralization related to the Snowdon Volcanic Group (Ordovician), Gwynedd, North Wales: Journal of the Geological Society, v. 142, p. 875-888.

Robinson, B. W., and Kusakabe, M. 1975. Quantitative preparation of sulfur dioxide, for 34S/32S analyses, from sulfides by combustion with cuprous oxide: Analytical Chemistry, v. 47, p. 1179-1181.

Rytuba, J. J., 1994, Evolution of volcanic and tectonic features in caldera settings and their importance in localization of ore deposits: Economic Geology, v. 89, p. 1687-1696.

Rytuba, J. J., Arribas A. Jr, Cunningham C.G., McKee E.H., Podwysocki M.H., Smith J.G., Kelly W.C. and Arribas A., 1990, Mineralized and unmineralized calderas in Spain; Part II, evolution of the Rodalquilar caldera complex and associated gold-alunite deposits: Mineralium Deposita, v. 25, p. 1432-1866.

Sangster, D. F., 1968, Relative sulfur isotope abundances of ancient seas and stratabound sulfide deposits: Proceedings of the Geological Association of Canada, v. 19, p. 79-91.

Schulz, K. J., 2012, Regional environment in volcanogenic massive sulfide occurrence model: U.S. Geological Survey Scientific Investigations Report 2010-5070-C, p. 33-60.

Sherlock, R. L., Roth, T., Spooner, E. T. C., and Bray, C. J., 1999, Origin of the Eskay Creek precious metal-rich volcanogenic massive sulfide deposit: fluid inclusion and stable isotope evidence, Economic Geology, v. 94, p. 803-824.

Slack, J. F., 2012, Hypogene gangue characteristics in volcanogenic massive sulfide occurrence model, U.S. Geological Survey Scientific Investigations Report 2010-5070-C, p. 151-153. 
Stix, J., Kennedy, B., Hannington, M., Gibson, H., Fiske, R., Mueller, W., and Franklin, J., 2003, Caldera-forming processes and origin of submarine volcanogenic massive sulfide deposits: Geological Society of America Bulletin, v. 31, p. 375-378.

Taylor, C.D., Zierenberg, R. A., Goldfarb, R. J., Kilburn, J. E., Seal, II, R. R., and Kleinkopf, M. D. 1996. Volcanic-associated massive sulfide deposits. Preliminary compilation of descriptive geoenvironmental mineral deposit models, Open-File Report 95-831, U.S. Geological Survey.

Thorpe, R. S., Beckinsale, R. D., Patchett, P. J., Piper, J. D. A., Davies, G. R., and Evans, J. A., 1984, Crustal growth and late Precambrian-early Palaeozoic plate tectonic evolution of England and Wales: Journal of the Geological Society, v. 141, p. 521-536.

Thorpe, R. S., Leat, P. T., Mann, A. C., Howells, M. F., Reedman, A. J., and Campbell, S. D. G., 1993, Magmatic evolution of the Ordovician Snowdon Volcanic Centre, North Wales (UK): Journal of Petrology, v. 34, p. 711-741.

Toman, H. C., 2012, Geology and metallogeny of North-Central Newfoundland and the Little Deer VMS deposit: an introduction and overview: Unpublished M.Sc. thesis, Newfoundland, Canada, Memorial University, p. 184.

van Staal, C. R., 2007, Pre-Carboniferous tectonic evolution and metallogeny of the Canadian Appalachians: Geological Association of Canada Special Publication No. 5, p. 793-818.

van Staal, C. R., and Barr, S. M., 2012, Lithospheric architecture and tectonic evolution of the Canadian Appalachians: Geological Association of Canada Special Paper 49, p. 41-95.

Wagner, T., Boyce, A. J., and Fallick, A. E., 2002, Laser combustion analysis of $\delta 34 \mathrm{~S}$ of sulfosalt minerals: determination of the fractionation systematics and some crystal-chemical considerations: Geochimica et Cosmochimica Acta, v. 66, p. 2855-2863.

Williams, F. M., Sheppard, W. A., and McArdle, P., 1986, Avoca Mine, County Wicklow: a review of geological and isotopic studies: in Andrew, C. J. et al., eds., Geology and genesis of mineral deposits in Ireland: Dublin, Irish Association for Economic Geology, p. 71-82.

Yeats, C. J., Hollis, S. P., Halfpenny, A., Corona, J. C., LaFlamme, C., Southam, G., Fiorentini, M., Herrington, R. J., and Spratt, J., 2017, Actively forming Kuroko-type volcanic-hosted massive sulfide (VHMS) mineralization at Iheya North, Okinawa Trough, Japan: Ore Geology Reviews, v. 84, p. 20-41.

Zaw, K., 2003, Geology and sulphur isotope implications of Bawdwin deposit, Northern Shan State, Myanmar: an Ag-rich, volcanic-hosted, polymetallic massive sulphide deposit, in Eliopoulos, D. G., ed., Mineral exploration and sustainable development, 7th Society for Geology Applied to Mineral Deposits Conference, Athens, Greece, 1: Athens, Greece, Millpress, Rotterdam, p. 217-220.

Zengqian, H., Zaw, K., Rona, P., Yinqing, L., Xiaoming, Q., Shuhe, S., Ligui, P., and Jianjun, H., 2008, Geology, fluid inclusions, and oxygen isotope geochemistry of the Baiyinchang pipe- 

Economic Geology, v. 103, p. 269-292. 
1237 Fig. 1. Location of the study area in north west Wales (red box) and geological map of the Snowdon area (based on British Geological Survey, 2013) showing the approximate extent of the caldera that existed during deposition of the Snowdon Volcanic Group according to Howells et al. (1986), the main mineral occurrences and approximate their orientation (grey line), and the rhyolite generations defined by Campbell et al. (1987): A1, A2, B1, B2 and B3 (see also Fig. 2). Abbreviations: CC = Cae Coch, $\mathrm{BN}=$ Benallt, $\mathrm{PM}=$ Parys Mountain.

Fig. 2. Generalized stratigraphic relationships of the Snowdon Volcanic Group (SVG) in the vicinity of Mount Snowdon: URTF $=$ Upper Rhyolitic Tuff Formation, BPF $=$ Bedded Pyroclastic Formation, LRTF = Lower Rhyolitic Tuff Formation, PT = Pitts Head Tuff Formation; and the sub-LRTF sediments: CEi = Cwm Eigiau Formation (adapted from Reedman et al. 1985; Howells et al. 1991). Also shown are the relative stratigraphic positions of the three phases of rhyolite based on Howells et al. (1991), and the approximate stratigraphic positions of the mineralized localities shown in Figure 1: 1. Britannia; 2. Cwm Tregalan; 3. Shadow Gully; 4. Lliwedd; 5. Hafod y Llan; 6. Braich-yr-Oen; 7. Hafod y Porth; 8. Caer Moch; 9. Nantmor; 10. Moel Hebog.

1251

1252

Fig. 3. 1: 50000 scale geological map (British Geological Survey, 2013) of the Beddgelert Fault Zone, showing the orientation of mineralized veins and the locations of the detailed Hafoy-y-Porth and Lliwedd mapping areas. B1 and B3 are distinctive rhyolite phases. The inset image shows the view toward the east-north-east from the western end of the Lliwedd structure. The white dashed line depicts the trace of the mineralized zone within the host BPF. Slivers of Upper Rhyolitic Tuff Formation (URTF) and B3 rhyolite (defined by the black dashed line) occur near the top of the ridge.

Fig. 4. Geological map and outcrop features of the Hafod-y-Porth mine area. A. Volcanic facies, structure and mineralization in the Hafod-y-Porth mine area (adapted from Jacobs, 2008). B. Rhyolite lapilli-tuff containing a $6 \mathrm{~cm}$-wide rhyolite fragment, which itself contains a quartz vein (locality HP4 in A); the inset rectangle shows an enlargement of the rhyolite fragment and contained vein. C. A 4 m-wide mined block, containing ramifying quartz-sulfide veins and disseminated sulfide mineralization, within an interval of pyroclastic breccia (locality HP3 in A). D. Network of transtensional, weakly mineralized, open-space quartz veins cutting across the silica ribs, which define the welded fabric in a welded rhyolite tuff (locality HP1 in A). E. The area shown by the black rectangle in (D) is enlarged in (E). The dilatational zone is occupied by rhyolite fragments cemented by quartz-sulfide veins.

Fig. 5. Photographs showing styles of mineralization and ore textures at Hafod-y-Porth. A. Steeply dipping, cleavage-parallel, quartz-sulfide vein cementing chloritized lithic fragments, within pyroclastic breccia (locality HP6 in Fig. 4.). The vein pinches and swells along strike, ranges from 1- 
$10 \mathrm{~cm}$ in width and contains chalcopyrite in milky white, microcrystalline quartz. Dashed line depicts approximate boundary of the vein, which is obscured by staining on the weathered rock surface. B. Chalcopyrite with subordinate euhedral pyrite hosted by microcrystalline quartz, which cements fragments within a lapilli-tuff (sample SMM41). C. Rhyolite breccia fragments cemented by quartz and predominantly galena. The quartz contains acicular crystals of graphite (sample SMM44). D. Rhyolite fragments (grey) cemented by quartz and sulfides (sample SMM85). E. The dark grey matrix of this rhyolite tuff contains disseminated chalcopyrite, and rhyolite clasts are cut by quartz-sulfide microveinlets. Fragments in the lower left have a jig-saw fit (SMM77). F. Basaltic tuff containing abundant sulfide infillings, stringers and disseminations composed of chalcopyrite and subordinate pyrite with no visible quartz (sample SMM66). G. Rhyolite cut by veinlets containing quartz and chalcopyrite. The rhyolite also contains finely disseminated chalcopyrite (sample SMM86). H. Section through a vein displaying multiple generations of variably textured quartz. The darker zones contain chloritized lithic fragments and intergrown chalcopyrite, pyrite and quartz (sample SMM68). Abbreviations: cp, chalcopyrite; ch, chlorite; cbQ, comb quartz; ds, disseminated; ga, galena; gp, graphite; lt, lithic fragment; mcQ, microcrystalline quartz; pyrite; Q, quartz; rhy, rhyolitic; sp, sphalerite.

Fig. 6. The relationship between the mineralization and the Bedded Pyroclastic Formation (BPF) at the Lliwedd mine. A. The distribution of volcanic facies adjacent to the main mineralized zone (adapted from Hodgins, 2009). B. View approximately east-west along the main mineralized zone, showing the relationship between the basaltic lapilli-tuff and adjacent pillow basalts (points A and B refer to locations shown on the map). C. Pillow basalts hosting sulfide-bearing quartz veins, which exploit the pillow lava boundaries and crosscut the unit. D. Detail of a discordant chalcopyrite-bearing quartz vein, with a limonitic halo crosscutting the pillow lavas. E. Discrete quartz fragments are sporadically distributed in the basaltic lapilli-tuff. F. The weathered surface of two quartz fragments has been removed and illustrates that the quartz-rich material represents discrete fragments separated by a tuffaceous matrix. G. Section through a quartz fragment removed from the tuff. The quartz contains chalcopyrite and disseminated pyrite. The pyrite is preferentially concentrated in dark chloritized zones (SMM144). Abbreviations: ch, chlorite; cp, chalcopyrite; ds, disseminated; lt, lithic fragment; pm, prismatic; py, pyrite; Q, quartz.

Fig. 7. Photographs showing styles of mineralization and ore textures at Lliwedd. A. Basaltic jigsaw breccia cemented by quartz and sulfides comprising mainly granular, subhedral to anhedral pyrite, with subordinate aggregates of chalcopyrite (sample SMM32). B. Semi-massive sulfide consisting of coarse-grained aggregates of chalcopyrite and sphalerite, with subordinate pyrite, galena and minor quartz (sample SMM30). C. Silica-sulfide rock, composed of microcrystalline quartz, euhedral to subhedral, zoned pyrite crystals and irregular masses of intergrown pyrite, chalcopyrite and pyrrhotite; iron stained quartz in the lower right is weakly banded, comprising layers of comb quartz and darker 
depositional layers (sample SMM114). D. Basaltic tuff, hosting a quartz-chalcopyrite vein containing angular lithic fragments and Mn carbonate; chalcopyrite is concentrated along the vein margin and around lithic fragments (sample SMM332). E. Irregular and complex quartz vein within dark chloritized tuff. The quartz hosts patches of intergrown chalcopyrite, pyrite and pyrhottite, and minor native copper. Comb quartz has nucleated on lithic fragments and larger prismatic crystals show growth zones (sample SMM201). F. Section through an asymmetric vein showing multiple stages of quartz-sulfide deposition (sample SMM137). G. Quartz veinlets containing intergrown pyrrhotite and minor chalcopyrite. Pyrrhotite is also disseminated in the altered rhyolite host rock (sample SMM27). $\mathrm{H}$. Microcrystalline quartz cementing fragments of basic tuff. Chalcopyrite and minor pyrite occur within and along the margin of the lithic fragments. Potassium feldspar is locally present at or near the margin of the quartz vein (sample SMM31). Abbreviations: cp, chalcopyrite; ch, chlorite; cbQ, comb quartz; ds, disseminated; ga, galena; 1t, lithic fragment; Mncb, manganese carbonate; mcQ, microcrystalline quartz; $\mathrm{Cu}$, native copper; Kfp, potassium feldspar; pm, prismatic; py, pyrite; po, pyrrhotite; Q, quartz; rhy, rhyolitic; sp, sphalerite.

Fig. 8. A-F, reflected light photomicrographs: A. Euhedral to subhedral, inclusion-free pyrite overgrowths surrounding deformed, inclusion-rich cores. Chalcopyrite occupies interstitial voids and fractures, and occurs as inclusions in the pyrite crystal cores (sample SMM187). B. Chalcopyrite and minor pyrrhotite filling fractures in pyrite. Minor galena and sphalerite is also present (sample SMM136). C. Contact (dashed line) between mafic wallrock (dark grey) and a quartz vein containing intergrown chalcopyrite and pyrite. The elongate crystals in the wallrock are ilmenite (sample SMM137). D. Semi-massive galena vein hosting anhedral domains of chalcopyrite and sphalerite, the latter contains abundant chalcopyrite inclusions (sample SMM106). E. Quartz containing blebs of pyrite and minor pyrrhotite, some of which are partly rimmed by graphite. Microfractures within the pyrite contain chalcopyrite (sample SMM85). F. Quartz-chalcopyrite-graphite vein. The graphite generally occurs as elongate fragments within the massive chalcopyrite (sample SMM134). G and H, SEM images: G. Euhedral magnetite and euhedral to subhedral pyrite throughout quartz vein and chlorite-rich wallrock. Also present are minor, disseminated, anhedral pyrite grains and aggregates of scheelite. Minor barite occurs in microveinlets that cross the sulfides and groundmass (sample KB888). H. Minute gold grains located at the contact between pyrite and chalcopyrite; gold also occurs as inclusions within the pyrite crystals (sample SMM136). Abbreviations: ba , barite; cp, chalcopyrite; ga, galena; gp, graphite; il, ilmenite; mg, magnetite; py, pyrite; po, pyrrhotite; Q, quartz; sc, scheelite; sp, sphalerite; wr, wall rock.

Fig. 9. Generalized paragenetic sequence for the Snowdon mineralization based upon ore petrography. It is not possible to establish the exact timing relationships between the two main mineral associations that can be distinguished in the caldera, but field relationships and Reedman et al. (1985) suggest the magnetite-rich assemblage is earlier or coeval with the base-metal rich mineralization; width of bars 
approximates the abundance of minerals and discontinuous lines indicate uncertainty over timing relationships.

Fig. 10. Histograms of new $\delta 34 \mathrm{~S}$ values of sulfides from the Snowdon mineralization and host rocks. A. $\delta 34 \mathrm{~S}$ values $(n=40)$ for mineralization from six mineral occurrences. B. $\delta 34 \mathrm{~S}$ values of unmineralized rocks from the Snowdon Volcanic Group and Myndd Mawr microgranite (Table 2).

Fig. 11. U-Pb concordia diagrams showing ID-TIMS data for samples from the Upper Rhyolitic Tuff Formation (URTF): SMM154; and Lower Rhyolitic Tuff Formation (LRTF): SMM157. Sample locations are shown on Figures 1, 2.

Fig. 12. Trace element diagrams for felsic volcanic rocks from the Snowdon Volcanic Centre and three VMS deposits in the British and Irish Caledonides. A. Nb-Y diagram from Pearce et al. (1984) for samples from Snowdon ( $(=49)$, Avoca $(n=6)$, Parys Mountain $(n=16)$, and Cae Coch $(n=4)$. B. Chondrite-normalized $(\mathrm{La} / \mathrm{Yb})_{\mathrm{n}}-\mathrm{Yb}_{\mathrm{n}}$ diagram showing the FI-FIV fields for felsic volcanic rocks (derived from data from Lesher et al. 1986; Hart et al. 2004), and different rhyolite types from the Snowdon Volcanic Centre $(n=19)$, Avoca $(n=4)$ and Parys Mountain $(n=21)$. Chondrite normalization values from McDonough and Sun (1995). C. Zr/Y-Y diagram showing the composition of Phanerozoic felsic volcanic sequences associated with VMS deposits globally (Lentz, 1998), and felsic rocks from Snowdon ( $n=49)$, Avoca $(n=6)$, Parys Mountain $(n=36)$, and Cae Coch $(n=4)$. D. Chondrite-normalized REE profiles for different rhyolite types from the Snowdon Volcanic Centre (mean of each rhyolite generation shown, $n=17)$, Avoca $(n=4)$, and Parys Mountain $(n=5)$. Source of data for Figure 12: Snowdon (Leat et al. 1986; Campbell et al. 1987; Howells et al. 1991; Thorpe et al. 1993), Avoca (Leat et al. 1986; McConnell, 1991), Parys Mountain (Leat et al. 1986; Barrett et al. 2001; Tim Barrett, pers. comm.), Cae Coch (Ball and Bland, 1985).

Fig. 13. Comparison of the bulk metal contents of Snowdon quartz-sulfide veins with VMS deposits in the Appalachian-Caledonian Orogenic belt and globally. Range, mean and median of values are indicated by the bars, circles and squares, respectively). Source of data: CC, Cae Coch (Ball and Bland, 1985; BGS unpub. data); PM, Parys Mountain (Micon, 2012); AV, Avoca (Moon and Hale, 1983); BW, Main Zone, Brunswick No. 12 (McClenaghan et al. (2009); VMS, Early Phanerozoic, bimodal-felsic VMS deposits (Barrie and Hannington, 1999).

Fig. 14. Comparison of $\delta^{34} \mathrm{~S}$ values for the Snowdon mineralization with those of potential sulfur sources and VMS deposits in the Appalachian-Caledonian orogenic belt; ranges are shown by horizontal bars and means by squares. 
1373 Fig. 15. Schematic interpretation of the marine and volcanic environment at the time of emplacement 1374 of the Snowdon mineralization, based upon the relationships at Lliwedd, where the mineralization is 1375 hosted by a shallow water, mafic volcanic sequence.

1376 


\begin{tabular}{|l|r|r|r|r|r|r|r|r|}
\hline \multirow{2}{*}{} & \multicolumn{3}{|c|}{ Quartz-sulfide $(\boldsymbol{n}=\mathbf{7 1})$} & \multicolumn{3}{|c|}{ Quartz-magnetite $(\boldsymbol{n}=\mathbf{1 1})$} \\
\cline { 2 - 8 } & \multicolumn{1}{|c|}{ Max. } & \multicolumn{1}{|c|}{ Min. } & \multicolumn{1}{|c|}{ Mean } & Median & Max. & \multicolumn{1}{c|}{ Min. } & Mean & Median \\
\hline Au & 0.624 & 0.002 & 0.144 & 0.090 & 0.096 & 0.002 & 0.010 & 0.001 \\
Cu & 156 & 0.20 & 28.0 & 11.7 & 190 & 2.3 & 74.7 & 39.2 \\
Pb & $>10000$ & 20.8 & 6412 & 9860 & 380 & 2.5 & 47.8 & 8.1 \\
Zn & $>10000$ & 10.7 & 2698 & 638 & 450 & 1.8 & 74.0 & 15.4 \\
Ag & $>10000$ & 51 & 2614 & 548 & 224 & 25 & 112 & 106 \\
Ni & 200.0 & 0.1 & 23.6 & 5.4 & 1.2 & 0.1 & 0.3 & 0.1 \\
Co & 134.8 & 0.20 & 18.9 & 12.2 & 83.8 & 1.1 & 29.4 & 22.3 \\
Mn & 737.6 & 2.4 & 72.7 & 33.7 & 511 & 5.3 & 75.4 & 32.4 \\
As & 710000 & 19 & 2955 & 2178 & 3287 & 293 & 1624 & 1162 \\
Sr & 7142 & 1.0 & 282.4 & 70.0 & 1361 & 1.0 & 145 & 10.0 \\
Cd & 77.0 & 1.0 & 9.5 & 5.0 & 33.0 & 1.0 & 7.5 & 2.0 \\
Sb & 1899 & 0.1 & 75.6 & 1.0 & 0.6 & 0.1 & 0.2 & 0.1 \\
Bi & 752 & 1.00 & 34.6 & 11.2 & 28.8 & 0.9 & 3.8 & 1.1 \\
V & 3885 & 0.1 & 241.6 & 49.4 & 25.5 & 3.9 & 10.5 & 9.9 \\
Ba & 432 & 2.0 & 94.7 & 72.0 & 230 & 11.0 & 108 & 93.0 \\
W & 1267 & 1.0 & 63.0 & 23.0 & 489 & 1.0 & 99.6 & 26.0 \\
Sn & 69.1 & 0.4 & 7.4 & 5.20 & 200 & 5.4 & 156 & 200 \\
Ta & 248 & 0.4 & 8.8 & 4.1 & 212 & 0.4 & 76.6 & 29.3 \\
\hline
\end{tabular}

1379 Table 1. Summary statistics based upon whole-rock analyses in parts per million for quartz-sulfide 1380 assemblages from the following localities: Lliwedd (25); Hafod-y-Porth (23); Hafod-y-Llan (7); 1381 Nantmor (7); Britannia (4); Braich-yr-Oen (2); Moel Hebog (2); and Caer Moch (1), and quartz1382 magnetite assemblages from Cwm Tregallan (7); and Shadow Gully (4). Values of 10,000 ppm were 1383 used for calculating mean and median values for $\mathrm{Cu}, \mathrm{Pb}, \mathrm{Zn}$ and $\mathrm{Mn}$, although maximum metal 1384 concentrations could be higher. 


\begin{tabular}{|c|c|c|c|c|c|c|c|}
\hline \multirow[b]{2}{*}{ Sample no. } & \multirow[b]{2}{*}{ Assemblage } & \multirow[b]{2}{*}{ py } & \multicolumn{5}{|c|}{ Sulfide } \\
\hline & & & sph & asp & po & сру & gal \\
\hline \multicolumn{8}{|l|}{ Britannia } \\
\hline SMM98-A2 & qtz-sulf & & & & & 12.7 & \\
\hline SMM98-A1 & & 12.9 & & & & & \\
\hline SMM98-A3 & & 12.9 & & & & & \\
\hline SMM98-A4 & & & & & & 11.6 & \\
\hline SMM120-A1 & qtz-sulf & & & & & 11.4 & \\
\hline SMM120-A4 & & 9.4 & & & & & \\
\hline SMM120-A2 & & & 12 & & & & \\
\hline
\end{tabular}

Lliwedd

SMM33-A1 qtz-sulf

12.4

SMM33-A3

11.2

SMM33-A2

9.6

\begin{tabular}{lcccc}
\hline SMM136-A2 & qtz-sulf & 9.1 & \multicolumn{2}{c}{} \\
SMM136-A3 & & & 9.7 & \\
\hline SMM137-B3 & qtz-sulf & & 13.3 \\
SMM137-A1 & & 11.5 & \\
SMM137-A2 & & & 11.8 \\
\hline
\end{tabular}

Hafod y Porth

SMM68-A2 qtz-sulf

12.4

SMM68-A1

12.5

SMM68-A4

10.9

SMM85-A2

qtz-sulf

15.6

SMM85-A4

19.5

SMM85-A1

22.3

SMM134-A1 qtz-sulf 15.8

SMM134-A4

SMM134-B1

15.1

SMM134-B2

14.6

Hafod y Llan

SMM106-1

qtz-sulf

15.9

SMM106-2

15.8

SMM106-3

15.8

SMM106-4

16.3 


\begin{tabular}{|c|c|c|c|}
\hline \multicolumn{4}{|l|}{ Nantmor } \\
\hline SMM16-A2 & qtz-sulf & 12.6 & \\
\hline SMM16-A1 & & & 14.3 \\
\hline SMM186-B3 & qtz-sulf & & 15.0 \\
\hline SMM186-A1 & & 13.8 & \\
\hline SMM186-B4 & & & 11.6 \\
\hline SMM187-B4 & qtz-sulf & 7.2 & \\
\hline SMM187-B5 & & 3.7 & \\
\hline SMM187-A1 & & 4.9 & \\
\hline \multicolumn{4}{|l|}{ Shadow Gully } \\
\hline KB888-5 & qtz-mag & 13.6 & \\
\hline KB888-6 & & 14.5 & \\
\hline KB1027-7 & qtz-mag & 16.1 & \\
\hline KB1027-8 & & 15.8 & \\
\hline \multicolumn{4}{|l|}{$\overline{L E R T F}$} \\
\hline SMM157 & & 13.4 & \\
\hline \multicolumn{4}{|l|}{$B P F$} \\
\hline SMM168 & & 7.2 & \\
\hline SMM181 & & 7.0 & \\
\hline \multicolumn{4}{|l|}{ B3 rhyolites } \\
\hline SMM129 & & 14.4 & \\
\hline SMM167 & & 18.5 & \\
\hline SMM118 & & 9.8 & \\
\hline \multicolumn{4}{|l|}{ Myndd Mawr } \\
\hline SMM161 & & 8.4 & \\
\hline
\end{tabular}

1387

1388 Table 2. New sulfur isotope data for mineralization from the Snowdon Caldera and unmineralized 1389 rocks from the Snowdon Volcanic Group and Myndd Mawr microgranite. All values are reported in $1390 \delta 34 \mathrm{~S}_{\mathrm{V}-\mathrm{CDT}}(\%)$. Abbreviations: py, pyrite; sph, sphalerite; asp, arsenopyrite; po, pyrrhotite; cpy, 1391 chalcopyrite; ga, galena; qtz, quartz; sulf, sulfide; mag, magnetite. 


\begin{tabular}{|c|c|c|c|}
\hline Characteristic & Volcanogenic massive sulfides & Snowdon & Expression in Snowdonia \\
\hline Geodynamic setting & Continental margin arcs and related backarcs ${ }^{1}$ & $\checkmark$ & Ensialic back-arc basin ${ }^{2}$ \\
\hline Tectonic regime & Extensional, resulting in graben subsidence ${ }^{3}$ & $\checkmark$ & Rift structure $^{4}$, transtensional regime ${ }^{5}$ \\
\hline Regional-scale setting & $\begin{array}{l}\text { Synvolcanic subsidence structures including } \\
\text { grabens and calderas }{ }^{1}\end{array}$ & $\checkmark$ & Asymmetric trapdoor caldera $^{6}$ \\
\hline Local structure & Synvolcanic faults and fissures ${ }^{1}$ & $\checkmark$ & $\begin{array}{l}\text { Intersecting basement faults, regional fracture } \\
\text { zones and volcano-tectonic structures related to } \\
\text { magma migration and subsidence }\end{array}$ \\
\hline Lithostratigraphy & $\begin{array}{l}\text { A range of submarine volcaniclastic rocks, with } \\
\text { mafic and felsic flows and domes, including } \\
\text { autobreccias, hyaloclastites, and their } \\
\text { redeposited equivalents, and synvolcanic minor } \\
\text { intrusions. Some sections may be subaerial }{ }^{1} \text {. } \\
\text { Proximal rhyolite facies associations }{ }^{3}\end{array}$ & $\checkmark$ & $\begin{array}{l}\text { Felsic and mafic primary and redeposited } \\
\text { pyroclastic material, related intrusive and } \\
\text { extrusive rocks, and their associated autobreccia, } \\
\text { hyaloclastite and redeposited equivalents }{ }^{7}\end{array}$ \\
\hline $\begin{array}{l}\text { Petrochemical } \\
\text { associations }\end{array}$ & Bimodal volcanic rocks ${ }^{3}$ & $\checkmark$ & $\begin{array}{l}\mathrm{A}>1000 \mathrm{~m} \text { thick sequence of bimodal volcanic } \\
\text { rocks }\end{array}$ \\
\hline Composition of felsic & Characterized by HFSE and REE enrichment, & $\checkmark$ & Subalkalic/peralkalic, within-plate signatures ${ }^{10,7}$. \\
\hline
\end{tabular}

${ }^{1}$ Franklin et al. (2005)

${ }^{2}$ Kokelaar et al. (1984)

${ }^{3}$ Allen and Weihed (2002)

${ }^{4}$ Campbell et al. (1988)

${ }^{5}$ Kokelaar (1992)

${ }^{6}$ Howells et al. (1986)

${ }^{7}$ Howells et al. (1991) 


\begin{tabular}{|c|c|c|c|}
\hline $\begin{array}{l}\text { rocks in evolved, post- } \\
\text { Archean terranes }\end{array}$ & $\begin{array}{l}\text { with calc-alkalic, within-plate (A-type) and/or } \\
\text { peralkalic signatures }{ }^{8} \text {. FII to FIII chemical types, } \\
\text { mainly the former }{ }^{8,9}\end{array}$ & & FII to FIIIb signatures (Fig. 11B) \\
\hline $\begin{array}{l}\text { Composition of mafic } \\
\text { rocks in evolved } \\
\text { continental arc to back- } \\
\text { arc environments }\end{array}$ & $\begin{array}{l}\text { MORB or alkalic (or within-plate, OIB } \\
\text { signatures) }\end{array}$ & & $\begin{array}{l}\text { Subalkalic, volcanic arc type, within-plate and } \\
\text { OIB signatures }{ }^{10}\end{array}$ \\
\hline Associated rocks & Exhalites $^{3}$ & $x$ & \\
\hline Heat source & Subvolcanic intrusions $^{1}$ & $\checkmark$ & $\begin{array}{l}\text { Sill-like reservoirs of mantle-derived basaltic } \\
\text { magma and high-level rhyolitic magma } \\
\text { chambers }{ }^{10,11}\end{array}$ \\
\hline $\begin{array}{l}\text { Timing relative to } \\
\text { magmatism }\end{array}$ & $\begin{array}{l}\text { Syngenetic, resulting from volcanically-derived } \\
\text { hydrothermal systems }{ }^{1}\end{array}$ & $\checkmark$ & $\begin{array}{l}\text { Field relationships indicate a temporal } \\
\text { association with the host volcanic rocks }\end{array}$ \\
\hline \multirow[t]{2}{*}{ Form } & $\begin{array}{l}\text { Concordant massive sulfide lenses, strata-bound } \\
\text { or banded sulfide facies }{ }^{1}\end{array}$ & $x$ & \\
\hline & $\begin{array}{l}\text { Discordant vein-type mineralization (stringer or } \\
\text { stockwork zone) }{ }^{1}\end{array}$ & $\checkmark$ & $\begin{array}{l}\text { Relatively narrow, steeply dipping, discordant } \\
\text { veins and stockworks; quartz-sulfide cemented } \\
\text { breccias; disseminated sulfides in wall rocks; } \\
\text { localized zones of semi-massive/massive sulfide }\end{array}$ \\
\hline
\end{tabular}

${ }^{10}$ Thorpe et al. (1993)

${ }^{8}$ Piercey (2011)

${ }^{9}$ Hart et al. (2004)

${ }^{11}$ Leat et al. (1986) 


\begin{tabular}{|c|c|c|c|}
\hline Sulfide minerals & $\begin{array}{l}\text { Pyrite-pyrrhotite-chalcopyrite-sphalerite- } \\
\text { galena }^{12}\end{array}$ & $\checkmark$ & $\begin{array}{l}\text { Pyrite-chalcopyrite-sphalerite-galena-pyrrhotite- } \\
\text { native copper }\end{array}$ \\
\hline \multirow[t]{4}{*}{ Gangue minerals } & Quartz $^{13}$ & $\checkmark$ & \\
\hline & Carbonate $^{13}$ & $x$ & \\
\hline & Barite $^{13}$ & $x^{14}$ & \\
\hline & White mica-chlorite $^{13}$ & $\checkmark$ & \\
\hline $\begin{array}{l}\text { Alteration associated } \\
\text { with stockwork vein } \\
\text { systems }\end{array}$ & $\begin{array}{l}\text { Chlorite-quartz-sulfide or sericite-quartz- } \\
\text { pyrite } \pm \text { aluminosilicates, with depletion in } \mathrm{Na} \\
\text { and } \mathrm{Ca}^{15}\end{array}$ & $\checkmark$ & $\begin{array}{l}\text { Intense K-metasomatism, strong Fe-Mg- } \\
\text { chlorite-quartz-pyrite alteration and elevated F } \\
\text { levels }{ }^{16}\end{array}$ \\
\hline $\begin{array}{l}\text { Geochemical } \\
\text { enrichments }\end{array}$ & $\begin{array}{l}\mathrm{Pb}, \mathrm{Zn}, \mathrm{Cu}, \mathrm{Au}, \mathrm{Ag}, \mathrm{Ba}, \mathrm{As}, \mathrm{Bi}, \mathrm{Co}, \mathrm{Se} *, \mathrm{Sn}, \\
\mathrm{Mn}, \mathrm{Cd}, \mathrm{In}^{*}, \mathrm{Bi}, \mathrm{Te}^{*}, \mathrm{Ga}^{*}, \mathrm{As}, \mathrm{Sb}, \mathrm{Hg}^{* 15} \text { (*not } \\
\text { analysed for present Snowdon study) }\end{array}$ & $\checkmark$ & $\begin{array}{l}\mathrm{Cu} \text {-rich, with lesser quantities of } \mathrm{Pb} \text { and } \mathrm{Zn} \text { and } \\
\text { elevated } \mathrm{Au} \text { and } \mathrm{Ag} \text { concentrations. Enriched in } \\
\text { a range of trace metals, notably } \mathrm{Bi} \text {, As and } \mathrm{Co} \text {, } \\
\text { but lower in } \mathrm{Sn}\end{array}$ \\
\hline $\begin{array}{l}\boldsymbol{\delta} 34 \boldsymbol{S} \text { values for sulfide } \\
\text { minerals in Phanerozoic } \\
\text { VMS }\end{array}$ & $-5.0 \%$ o to $+20.7 \%{ }^{17}$ & $\checkmark$ & $\begin{array}{l}\text { Snowdon mineralization has a mean: }+13.0 \% \mathrm{~m} \pm \\
3.4 \% \mathrm{~m}\end{array}$ \\
\hline Water depth & Relatively deep marine settings ${ }^{3,18}$ & $x$ & $\begin{array}{l}\text { Shallow water marine conditions, with periodic } \\
\text { subaerial conditions } 6,7,19\end{array}$ \\
\hline
\end{tabular}

${ }^{12}$ Koski (2012)

${ }^{13}$ Slack (2012)

${ }^{14} \mathrm{With}$ the exception of trace quantities of barite at Shadow Gully

${ }^{15}$ Galley et al. (2007)

${ }^{16}$ Ball and Colman (1998)

${ }^{17}$ Huston (1999)

${ }^{18}$ Hannington et al. (2005)

${ }^{19}$ Howells and Smith (1997) 


\begin{tabular}{|l|l|l|l|}
\hline Environment & $\begin{array}{l}\text { Tectonic stability, with hiatuses in volcanic } \\
\text { activity }^{20}\end{array}$ & $\mathbf{x}$ & $\begin{array}{l}\text { No evidence for periods of tectonic stability or } \\
\text { volcanic quiescence; high-energy, marine } \\
\text { environment }^{7}\end{array}$ \\
\hline
\end{tabular}

Table 3. Comparison of the main geological, tectonic and geochemical features of the Snowdon mineralization with those of VMS deposits hosted by Phanerozoic bimodal-felsic sequences globally. 


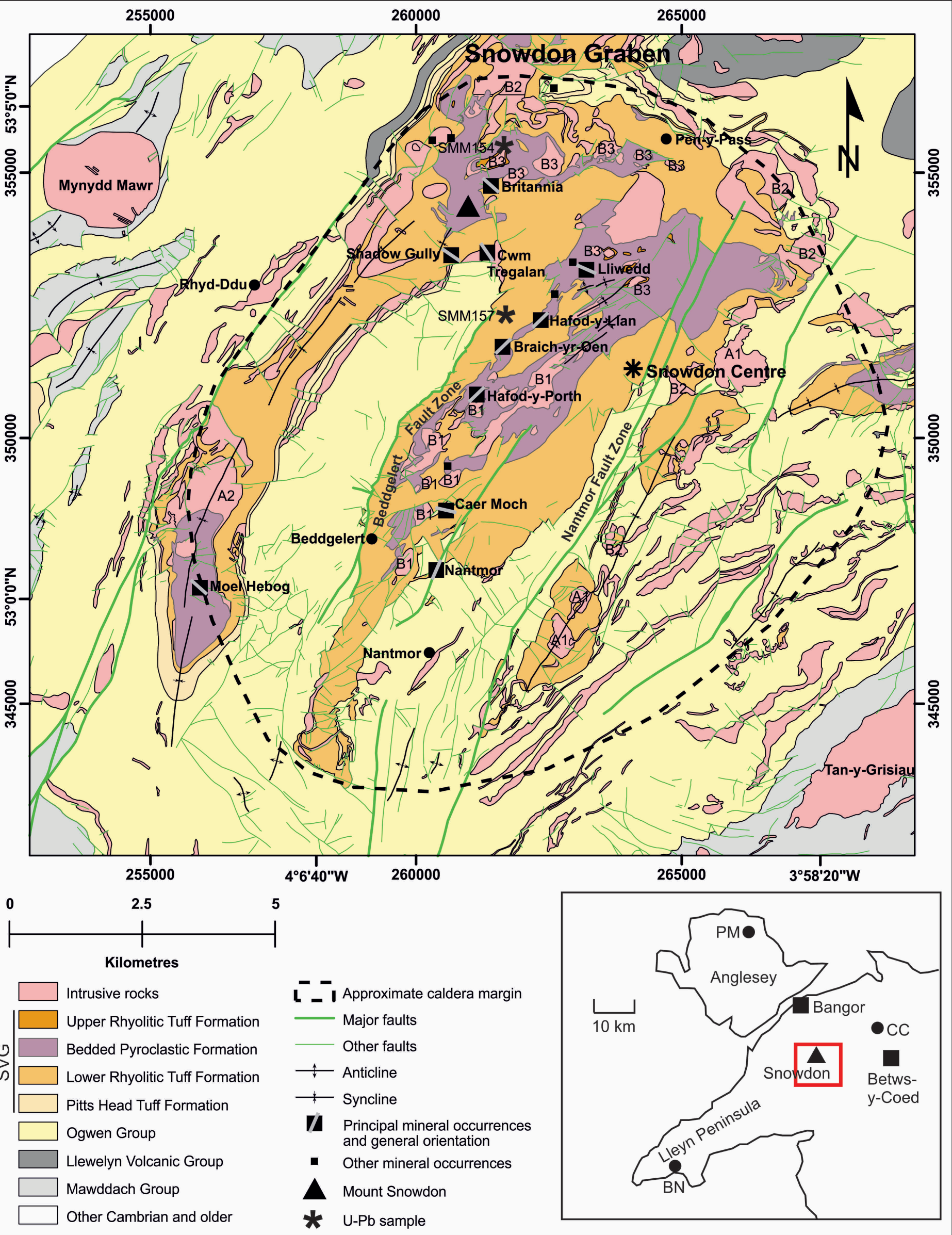


NE

Snowdon

SW

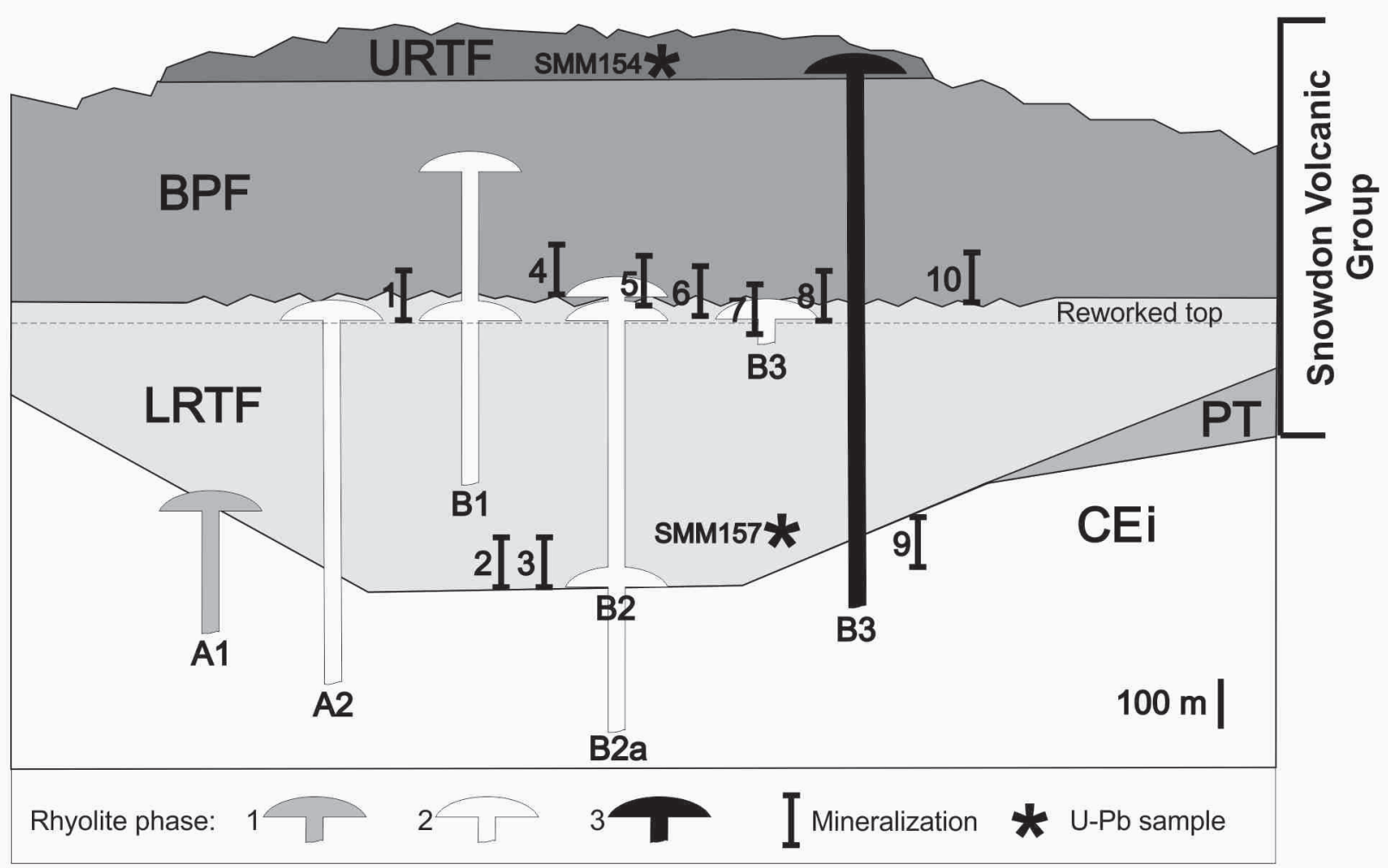




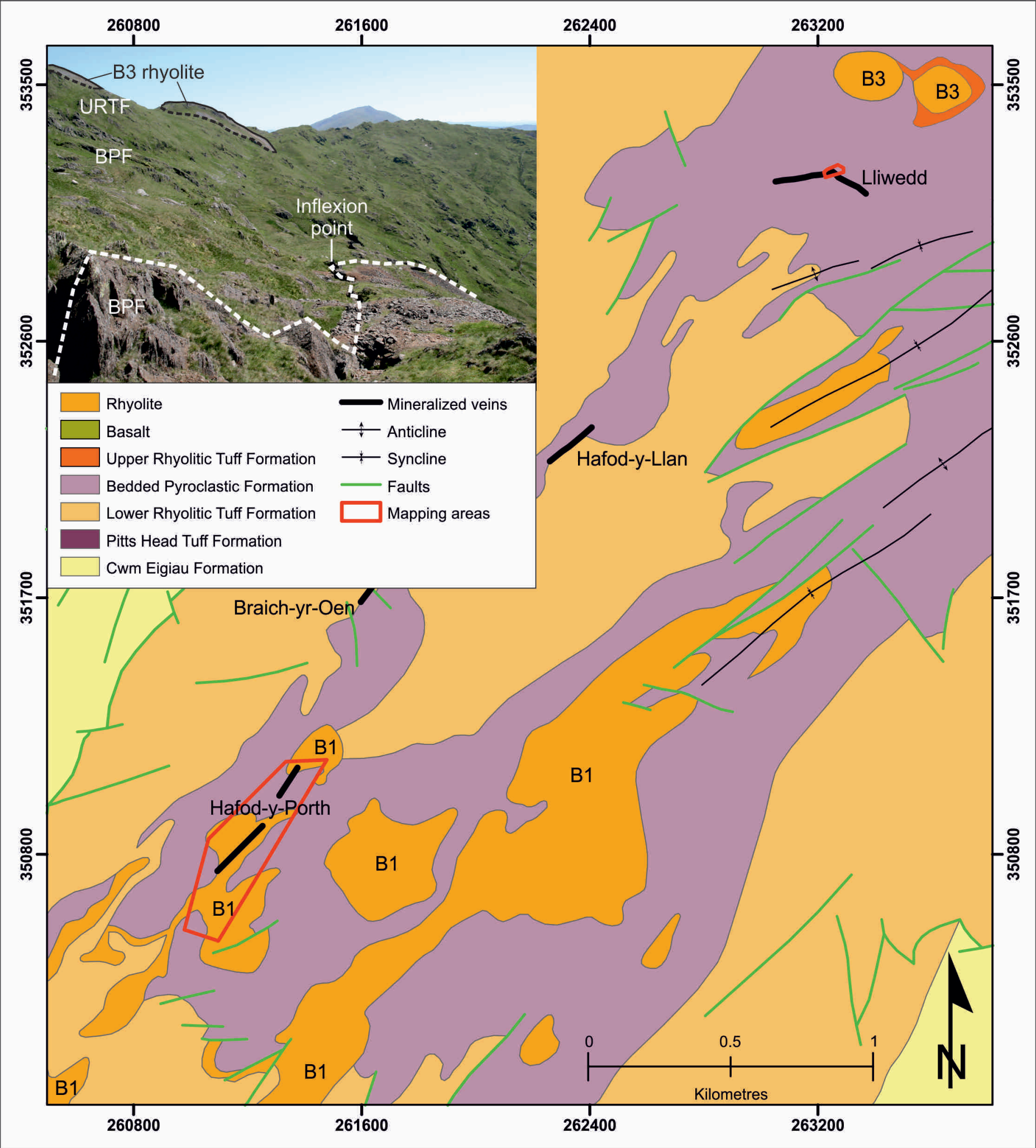




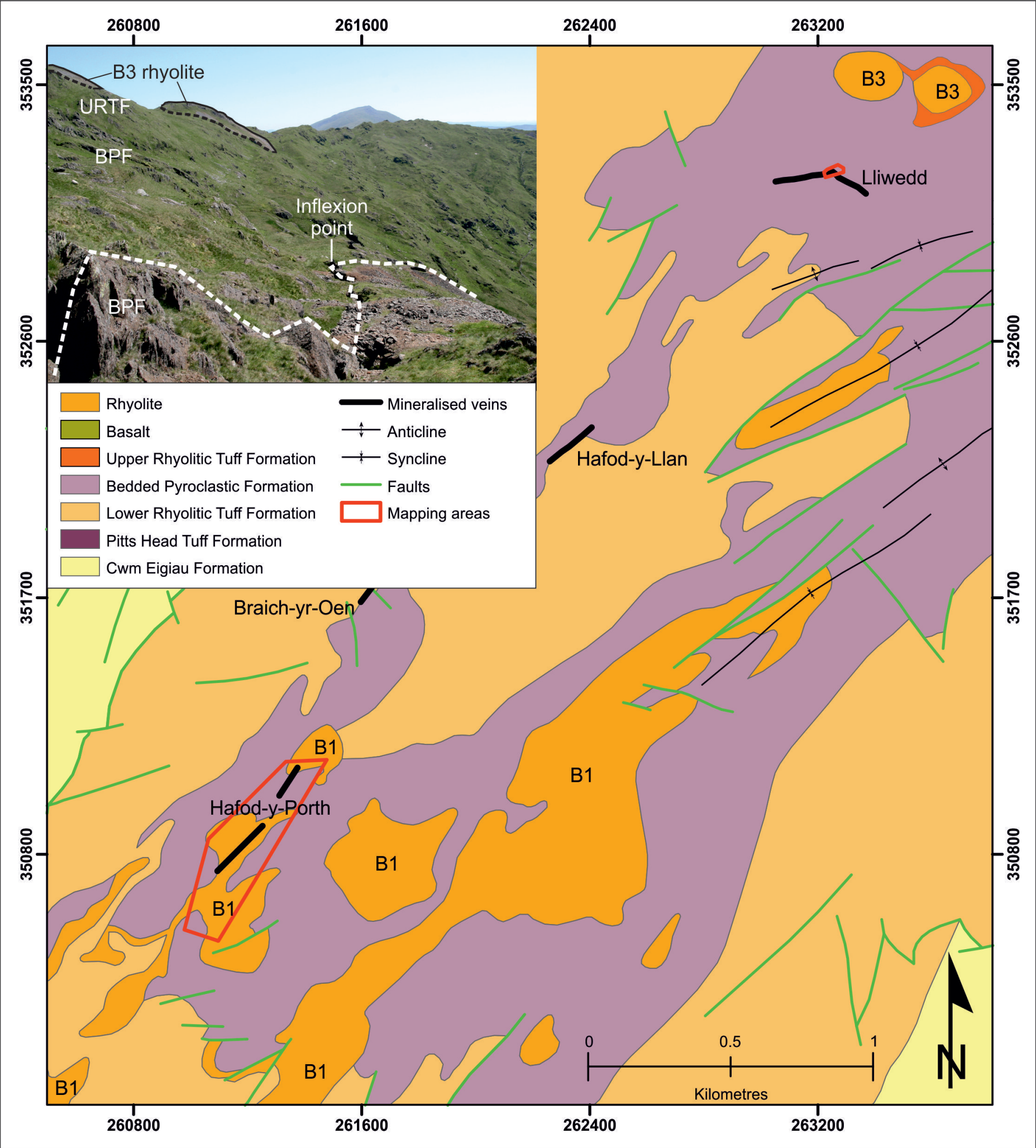




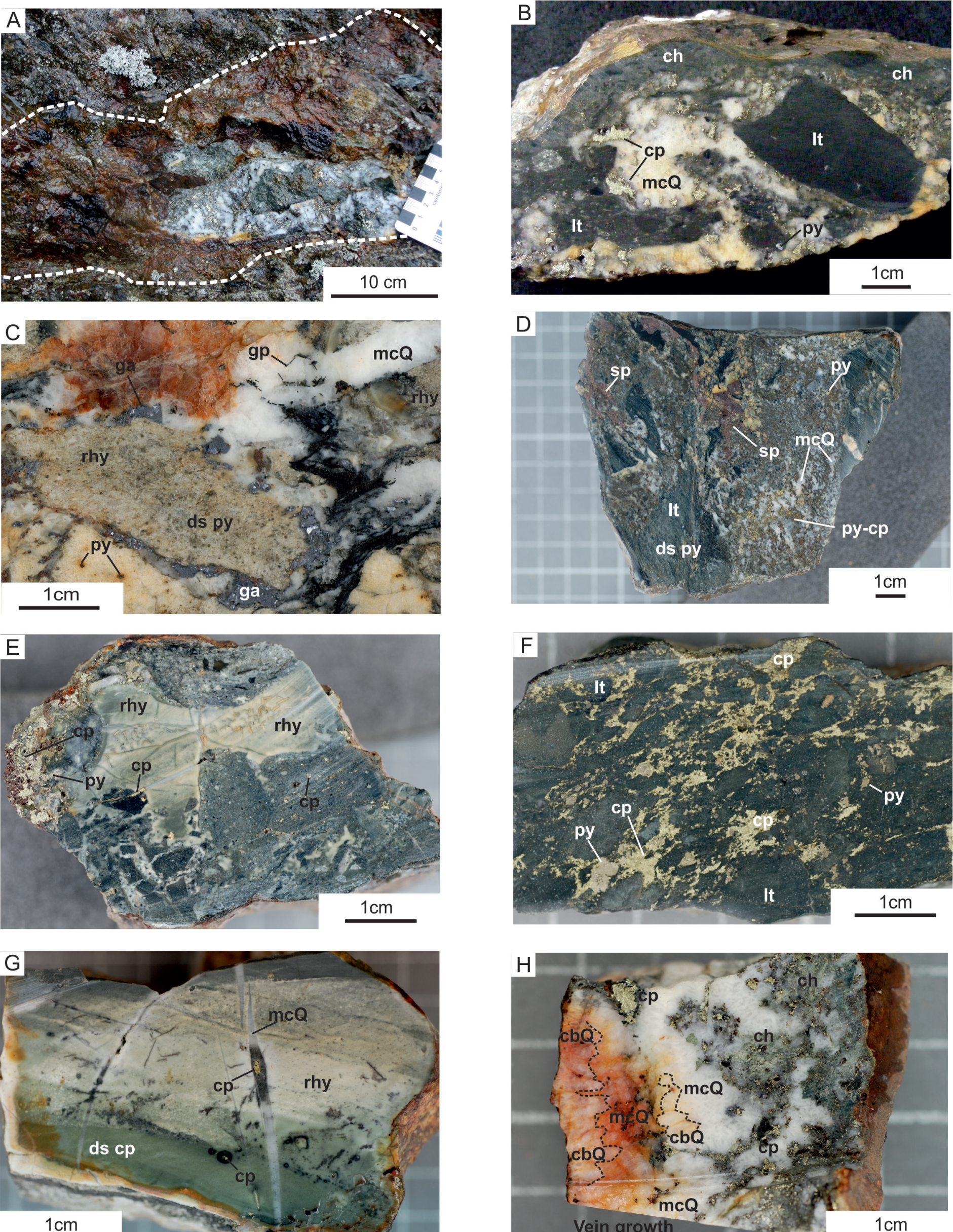



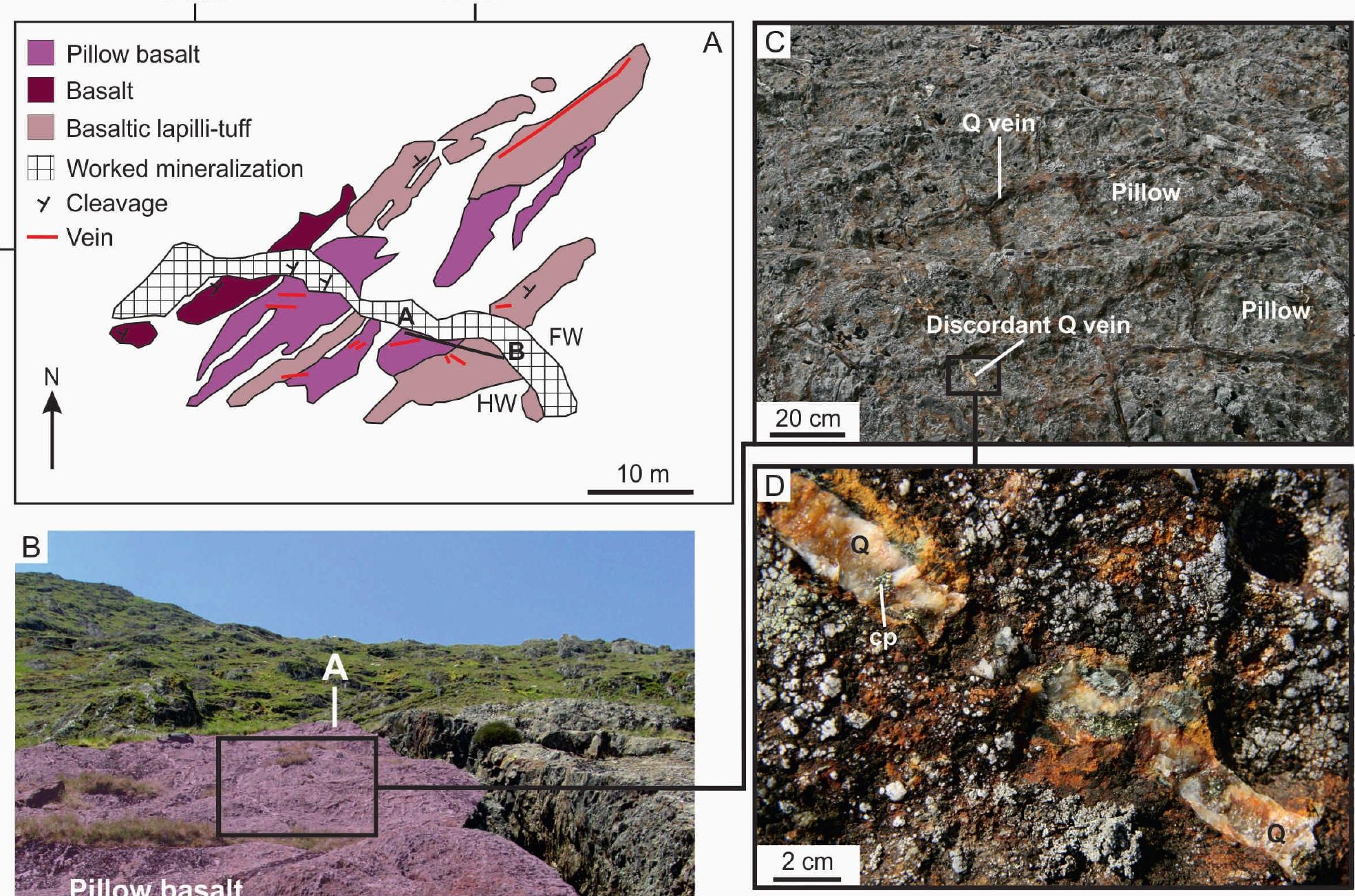

Pillow basalt
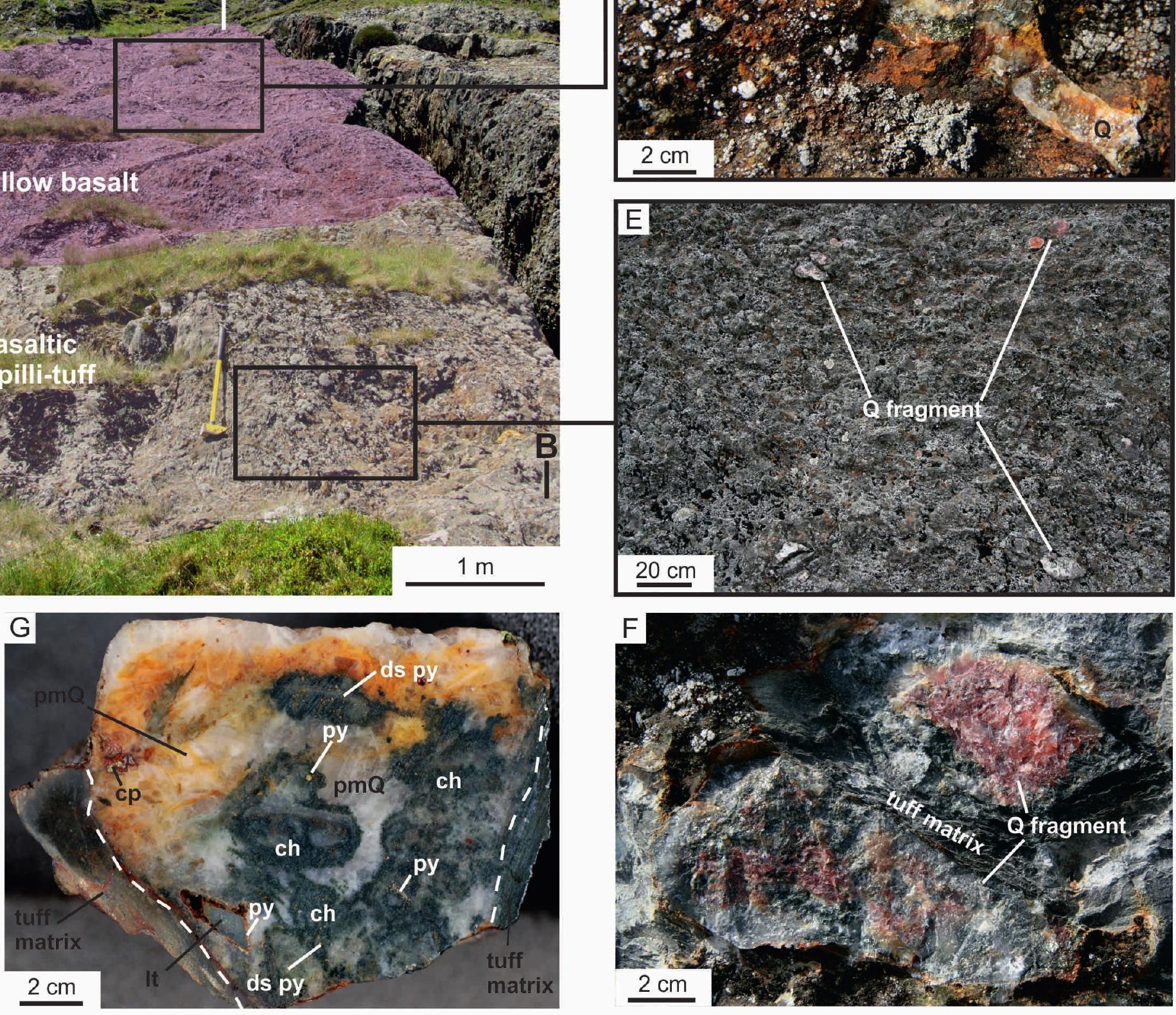

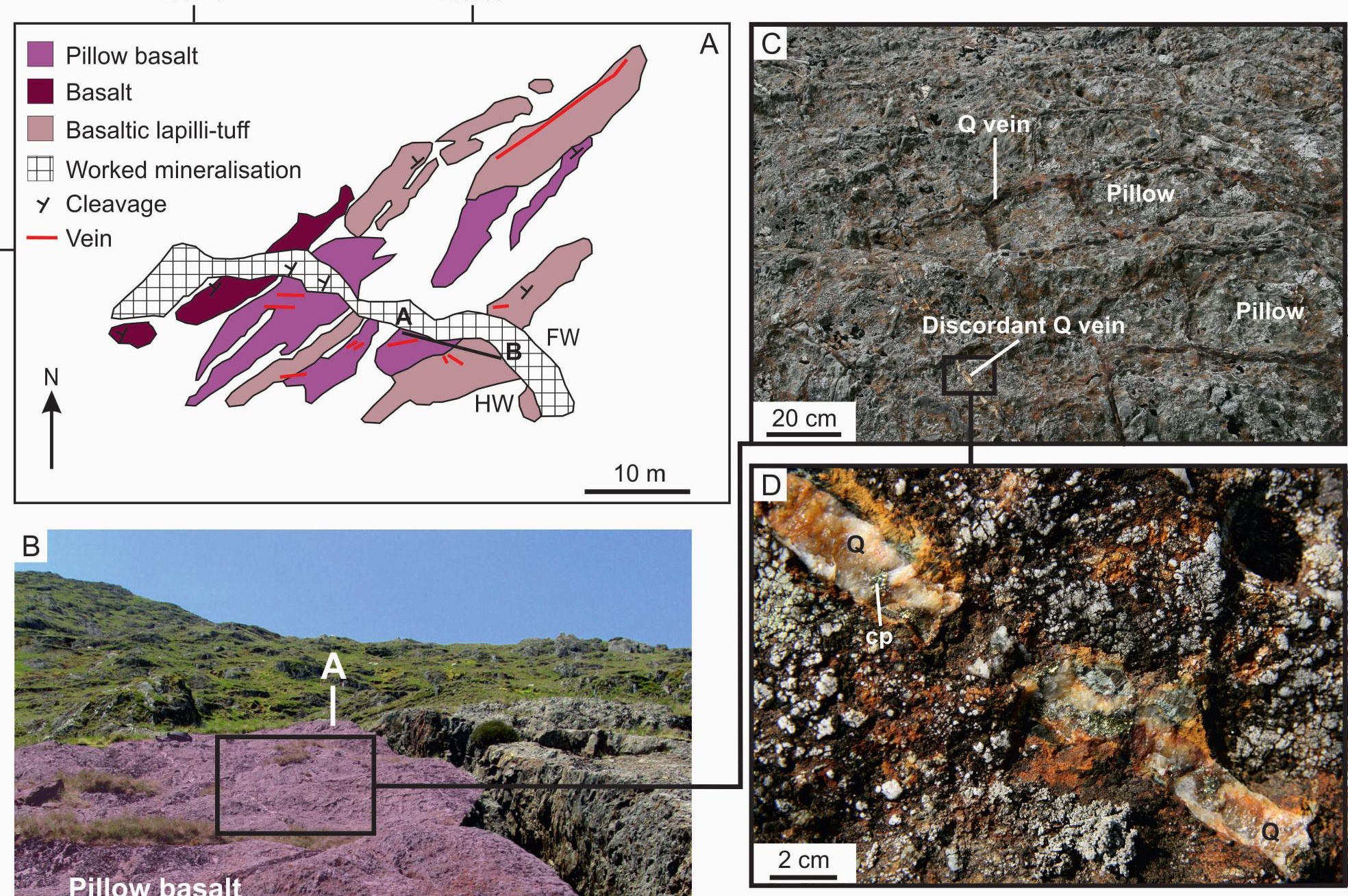

Hilow basalt
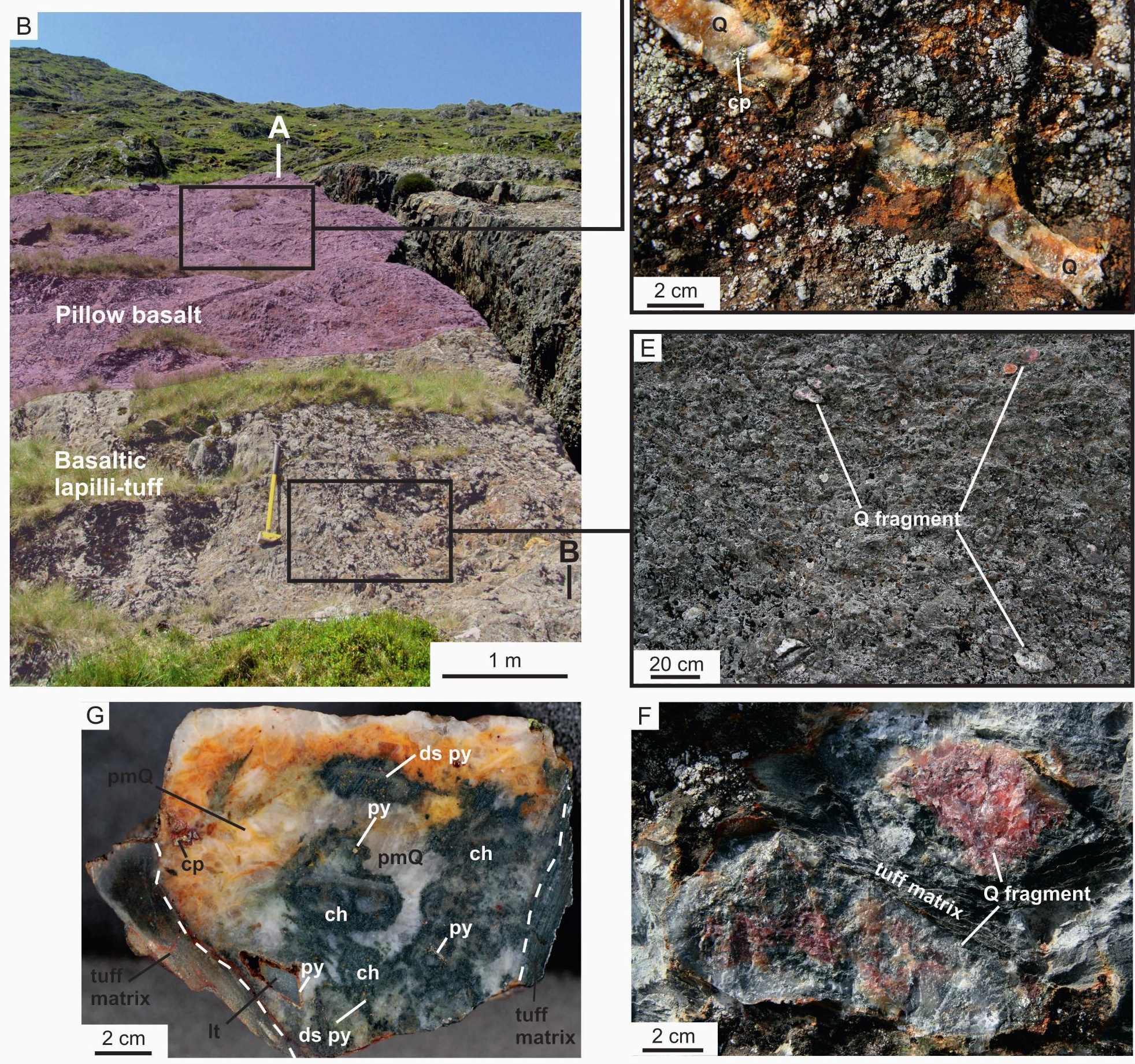


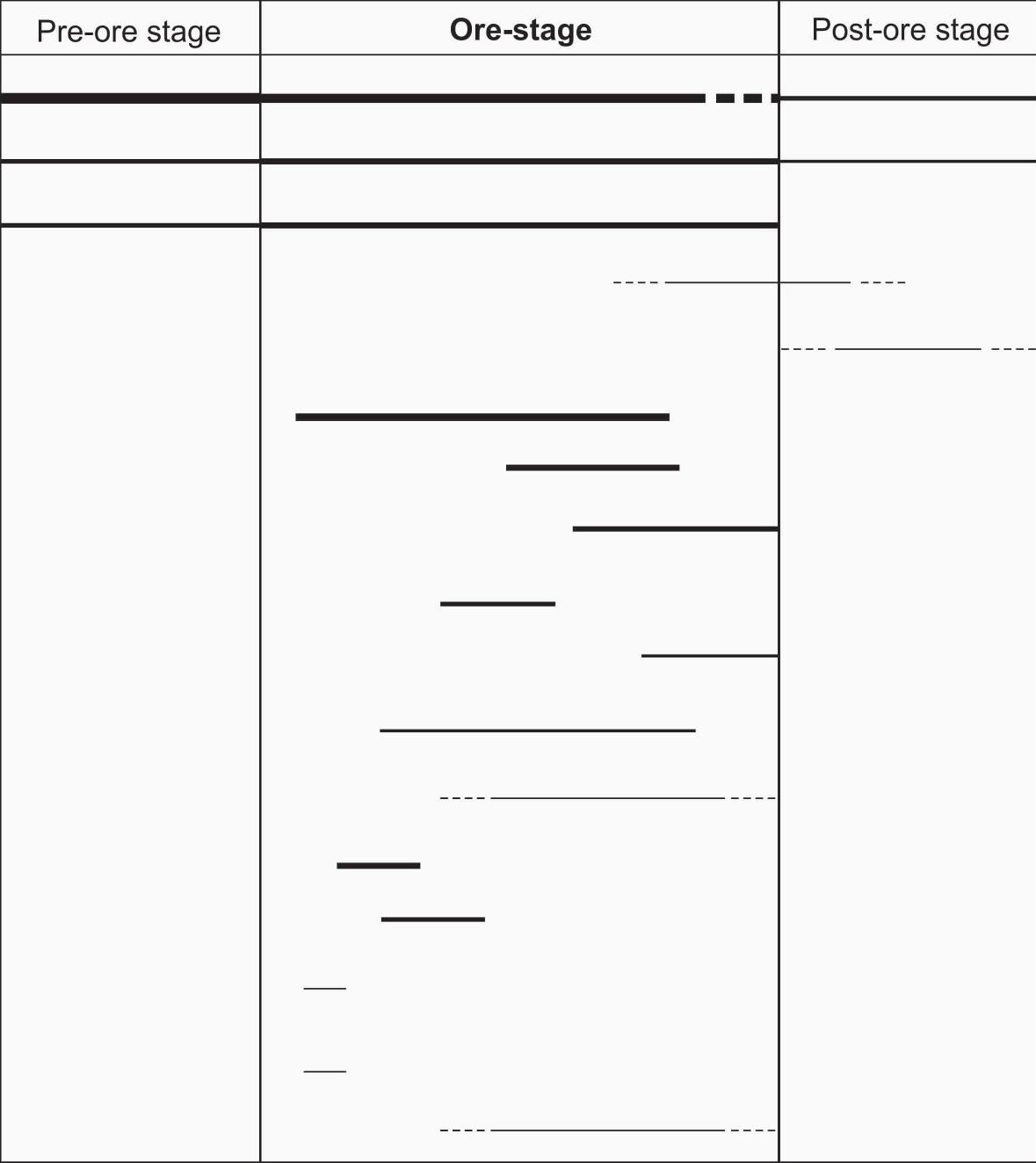


Data-point error ellipses are $2 \sigma$

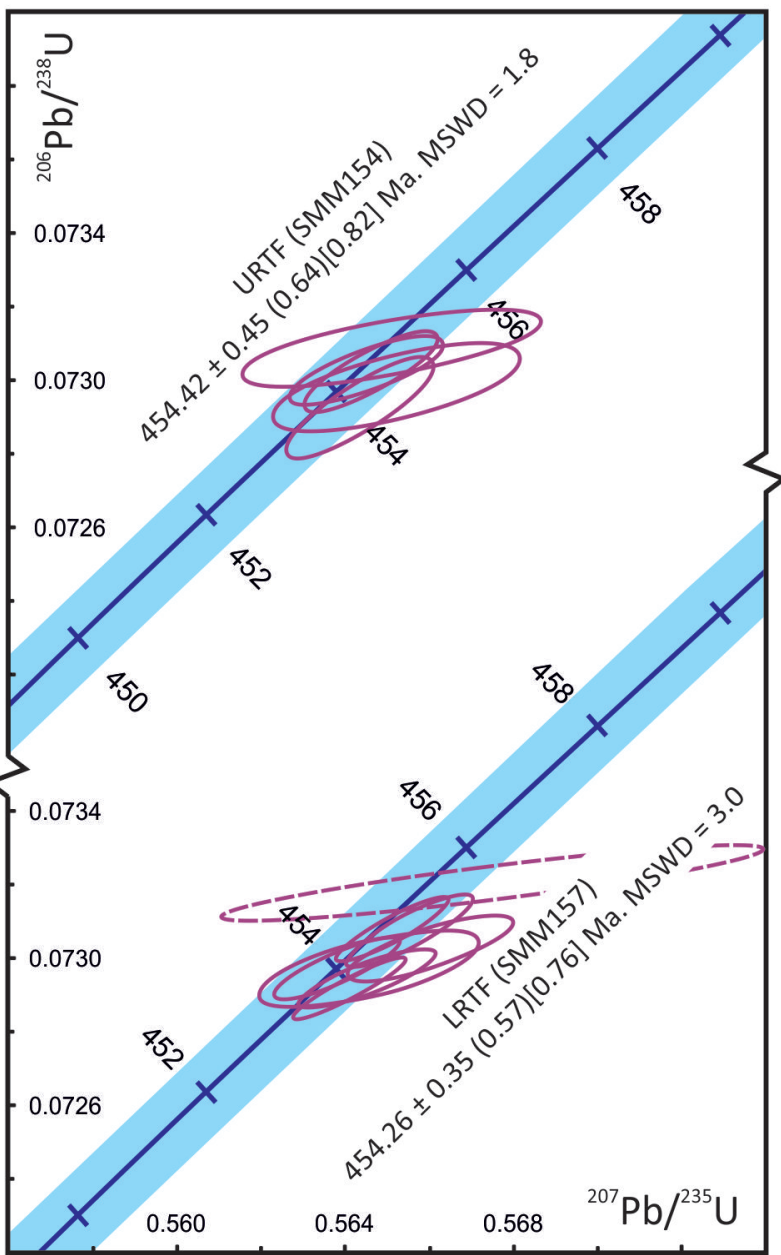




\section{Snowdon mineralization}

Volcanic-hosted quartz-sulfide mineralization

Quartz-magnetite mineralization

Sedimentary rock-hosted quartz-sulfide mineralization (Nantmor)

\section{Potential sulfur sources}

Typical range of magmatic sulfur (Ohmoto, 1986)

Ordovician seawater sulfate (Claypool et al. 1980)

Snowdon Volcanic Group

\section{VMS mineralization}

Ordovician VMS deposits globally (Huston, 1999)

Cae Coch deposit, North Wales (Bottrell and Morton, 1992)

Parys Mountain deposit, North Wales (Unpublished results)

Carreg-y-Dol zone

Western end of property

Central shales stockwork

Avoca deposit, Ireland (Williams et al. 1986)

Massive, disseminated and vein mineralization

Mineralized rhyolite, East Avoca

Brunswick No. 12, Bathurst, Canada (Goodfellow and Peter, 1996)

Bedded Ore

Vent Complex

Stockwork

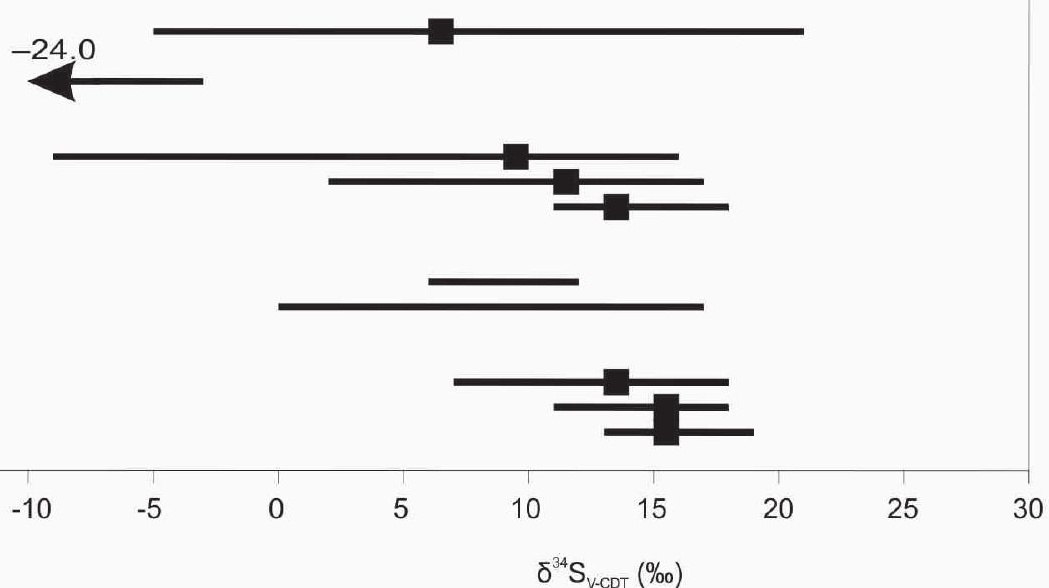




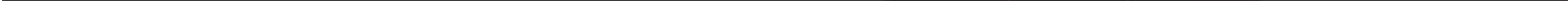

